\title{
PROLEGOMENA TOT EEN THEORIE DER WOORDSOORTEN IN INDONESISCHE TALEN *)
}

\author{
DOOR
}

J. GONDA.

Een der grote moeilijkheden die zich bij de descriptieve grammatika van een Indonesische taal hebben voorgedaan betreft de classificatie van het woord-materiaal, de lexikale kategorieën, de 'parts of speech' of woordsoorten. Vele auteurs hebben deze moeilijkheden niet of nauwelijks beseft en het Indonesische taalmateriaal gewrongen in het traditionele tiendelige schema van de Europese schoolgrammatika: zelfst. naamwoord, bijvoeg. naamwoord etc., zonder te beseffen, dat reeds voor hun moedertaal, Nederlands of Engels, deze indeling hoogst onbevredigend is. Anderen, zoals reeds Marsden ${ }^{1}$ ), zagen wel bezwaren, maar kwamen niet tot ingrijpende wijzigingen. Typerend is de houding van Spat ${ }^{2}$ ) die betoogt, dat de verdeling in woordsoorten (men lette op de term: verdeling: de auteur van de grammatika verdeelt, legt zijn schema op) voor het Maleis niet in alle opzichten bruikbaar is, maar daaraan toevoegt, dat dit niet uitsluit, dat bij de bespreking van de woordsoorten deze verdeling toch ook gemakken en voordelen oplevert. Weshalve hij achtereenvolgens negen van de tien traditionele woordsoorten - alleen het lidwoord ontbreekt - de revue laat passeren ${ }^{3}$ ).

Hoewel uitdrukkelijk vastgesteld moet worden, dat het traditionele systeem, dat in hoofdzaak uit de klassieke oudheid stamt, een belang-

*) Dit artikel is een bewerking van een sinds 1935 meermalen omgewerkt en uitgebreid college. Voor de redactie van bepaalde delen dank ik suggesties aan discussies over dit onderwerp met A. W. de Groot.

1) Marsden-Elout, Maleische Spraakkunst, 1824, p. 48, geciteerd in mijn Taalbeoefening en Taalbeschouwing, Bijdragen 99, p. 31 vlg.

$\left.{ }^{2}\right)$ C. Spat, Maleische Taal. Overzicht van de Grammatica ${ }^{4}, 1920$, § 57 en 58.

3) Over een en ander ook mijn Taalbeoefening en Taalbeschouwing, Bijdragen 99 , p. 31 vlg. en p. 18 . Men vergete echter niet, dat al eeuwen lang de onderscheiding in woordsoorten mede praktische, didaktische belangen gediend heeft. 
rijke intellectuele praestatie vertegenwoordigt, moet men daar tegenover stellen, dat al in de oudheid zelf bezwaren er tegen werden gevoeld, bezwaren zo groot, dat de Romeinse grammaticus Varro het al met een ander systeem van vier woordklassen probeerde. Een der moeilijkheden betrof, al vroeg, de interjectie. Staat deze op één lijn met de andere kategorieën? Misschien zijn interjecties als lat. vale, age, ned. wel, goed, mal. baiklah nog betrekkelijk gemakkelijk onder te brengen, maar vele talen kennen interjecties die zich van andere woorden door fonematische bijzonderheden onderscheiden. In pst!, dat in Nederlands en Engels in gebruik is om stilte op te leggen, treedt de $s$ als syllabe-vormend element op. Waar moet men zo'n woord dat zich niet houdt aan het normale fonematische patroon van een taal onderbrengen? Bovendien zijn interjecties van het type ned. $o$, au, ĕh, tut, eng. ouch, sh, gosh in een flexierijke taal duidelijker een afzonderlijke groep dan in een taal als het Soendaas, waar talrijke werkwoordelijke tussenwerpsels en dergelijke woordjes bestaan. In het Soendaas is $t u t=t o p$ een wwd. tuss. voor ,aanpakken, (aan)nemen", $o h$ is er een interjectie die in de regel een lichte afkeuring vertolkt, $a h, \breve{e} h$, ih hebben een functie van overeenkomstige aard, $u h$ echter geldt als wwd. tuss. voor duuh ,afdruppelen”. En woordjes van deze aard kunnen er ten grondslag liggen aan grondwoorden en afleidingen: tes ,tik" is onomatopee voor het geluid van een vallende druppel, wwd. tuss. voor "druppelen”: tetes betekent „druppelen, druppel”.

Vendryes ${ }^{1}$ ) merkt op, dat de interjectie apart staat, dat ,elle a en soi quelque chose qui la met à part des autres parties du discours, elle ne peut être rangée dans un même classement"; een interjectie als fr. pff heeft, zegt hij, in het algemeen niets met de morfologie te doen. „Elle (l'interjection) représente une forme spéciale du langage, le langage affectif ..., elle reste en dehors de la structure du langage intellectuel". Maar dit alles is geen reden om de interjectie buiten te sluiten, om haar te negeren. Wij dienen onze belangstelling niet te beperken tot „le langage intellectuel”. Al te zeer heeft men dit gedaan en al te zeer heeft men ,onze taal”, waaronder men ten naaste bij het papieren Nederlands of Duits of Engels van het zakelijke of wetenschappelijke geschrift verstond, als normaal beschouwd. Al wat tot de affectieve taal behoort verdient evenzeer onze belangstelling. Hoe weinig grijpbaar het soms ook is. Een meermalen gevoelde moeilijk-

I) J. Vendryes, Le langage, 1921, p. 136. 
heid bij de interjecties is hun al gereleveerde veelsoortigheid: behalve de 'amorfe', waarbinnen men weer kan onderscheiden die met ongewone fonemen ( $p s t)$ en die met gewone fonemen in ongewone opeenhoping of volgorde (ned. ah), die van het type loop, verdomme, verrek, gossie-pietje, en de afgrenzing daarvan tegenover de zgn. ellipsen als nonsens!

Bally ${ }^{1}$ ) heeft voorgesteld de interjecties te beschouwen als zgn. monoremen en of mots-phrases, als woorden die op zichzelf een hele zin vormen: hei!, magnifique!, klets! Ze hebben intonaties die hun zinskarakter bevestigen, de intonatie van fr. gare!, dat waarschuwend is, is anders dan die van ouf !, dat een verlichting of verademing uitdrukt. Door transpositie - treden in de functie van andere lexikale kategorie $^{2}$ ) - kunnen ze woorden worden: fr. patatras, interj. van iets dat valt: un patatras ,een val”. Men zou kunnen zeggen, dat interjecties grensgevallen vertegenwoordigen onder de lexikale kategorieën. Ze onderscheiden zich o.a. door een sterk affectief, subjectief element. In een taal als het Soendaas worden ze werkwoord als ze geheel als zodanig fungeren: tö daèk pok ,hij is niet willens te spreken"; en, op overeenkomstige wijze, substantief : $A$. nambala $\dot{n}$, pokna ,...A. viel in de rede, zeggende :...”. Echte interjecties of als zodanig fungerende woorden laten zich echter niet in syntaktisch ondergeschikte positie gebruiken; men kan ze hoogstens aaneenreigen, in nevenschikking achter elkaar voegen ${ }^{3}$ ).

Er zijn, in het kort gezegd, verschillende wegen bewandeld om tot een indeling van het woord-materiaal ener taal te komen. De oude Grieken probeerden een classificatie op te stellen tegelijk met die der ontologische en logische kategorieën: het substantief duidt aan een zelfstandigheid, het adjectief een hoedanigheid. Daarbij gold het principe een woord tot slechts één kategorie te rekenen. Ook Vendryes stelt nog in deze eeuw zijn vertrouwen op een logische indeling, die voor alle talen geldig zou zijn en die door de grammatika van althans de belangrijkste talen niet tegengesproken zou worden. Deze laatste beperking is tekenend! ${ }^{4}$ ) Maar hij heeft niet alleen uitvoerige kritiek op de traditionele classificatie, hij betoogt ook, dat ,cette classification

1) Ch. Bally, Linguistique générale et linguistique française, 2e ed.; Bern $1944, \S 177$.

2) Zie beneden, p. 282.

3) Daarbij ook: R. Lenz, La oración y sus partes, Madrid 1935, p. 91 vlg.

$\left.{ }^{4}\right)$ Vendryes, o.c., p. 158: „On voit qu'une classification générale des mots d'une langue n'est pas impossible, sur un plan que la logique justifie et que la grammaire des principales langues ne contredit pas." 
logique n'est pas la seule qu'admettent les mots d'une langue". De „,mots vides” (fr. que, $d e$ ) en de interjecties vallen bij zijn groepering $\mathrm{af}^{1}$ ): hun karakter is immers de abstractie, ja vaak zijn ze symbolen, die in een andere taal niet vertaald kunnen worden, zoals gr. äv en skt. iti. Tegen deze kijk op de zaak kan men bezwaar hebben: al hebben deze woorden wat hun intellectueel-omschrijfbare, in begrippen uitdrukbare betekenisinhoud betreft hun eigenaardigheden bij substantiva, verba etc. vergeleken, het valt niet te ontkennen, dat ze evengoed lexikale entiteiten zijn. En al is de 'betekenis' van een interjectie niet een begrip als die van een substantief, taal dient niet alleen tot 'Darstellung', maar ook tot 'Ausdruck' of appel ${ }^{2}$ ) en een lexikale grootheid die speciaal deze laatste dient, zoals de interjectie, zou ik daarom niet uit de rij der woorden schrappen.

Hoever moet men overigens de door Vendryes aanbevolen weg gaan zonder zich in conflict te gevoelen met de grammatika der voornaamste talen? En wat zijn de voornaamste talen?

Definities van woordsoorten op grond van logisch-intellectuele begripsinhoud, classificatie in verband met ontologische kategorieën zijn voor Indonesische talen ook meermalen voorgesteld. Morris ${ }^{3}$ ) verstaat voor het Mentawai onder een nomen ,die Bezeichnung von etwas in der Aussenwelt sich der Wahrnehmung Darbietendem, und zwar in allen seinen Beziehungen, durch die es je nach Umständen als Ding, Thätigkeit oder Eigenschaft erscheint: abak „Boot: Boot fahren",".Verder onderscheidt hij Personenwörter, Fragewörter, hinweisende Wörter, Partikeln, Interjektionen, Eigennamen. Deze en dergelijke pogingen een correlatie tot stand te brengen tussen enerzijds lexikale, anderzijds ontologische of 'begriffliche' Kategorieën blijken echter al spoedig onbevredigend te zijn, vooral wanneer men zich aan het traditionele tiental woordsoorten houdt. De vraag welke ontologische kategorieën aan bepaalde woordsoorten beantwoorden is geen linguistisch probleem, hoe interessant het kan zijn over de verhouding van deze niet met elkaar kloppende klassen van kategorieën na te denken. De conventionele classificatie is dan ook slechts een vage onzekere benadering van logische en ontologische kategorieën, hoezeer men zich moeite heeft gegeven om te betogen, dat ieder werkwoord per se een ,werken", een handeling aanduidt en ieder

1) Over mots vides Vendryes, o.c., p. 200 vlg.

2) Over interjecties bv. K. Bühler, Sprachtheorie, 1934, p. 297 ,

3) M. Morris, Die Mentawai-Sprache, 1900, p. 7. 
adjectief een eigenschap. Aan skt. rajyati, dat een werkwoord is, beantwoordt nederl. hij (zij, het) is rood; het Engels kan „rood zijn” niet anders uitdrukken dan met een adj.: to be red, it is red, maar „rood worden” kan zijn redden: it reddens, wat wil zeggen ,het krijgt de eigenschap rood". In het Latijn is rubet (werkwoord) = est ruber (zgn. koppelwerkwoord + adj.) en in het Nederl. is rood zijn vaak „blozen” (werkwoord). Aan lat. aegrotare (wwd.) beantwoordt ned. ziek zijn. Men kan dezelfde idee, meermalen zelfs in dezelfde taal met een adj. en met een wwd. uitdrukken. En skt. rajyati, lat. rubet zijn evenzeer werkwoorden als atti ,hij eet”, delet „hij vernietigt”. En in vele talen is het gewoon op een andere wijze uit te drukken wat wij met een werkwoord plegen aan te duiden ${ }^{\mathbf{1}}$ ). En Morris' betoog, dat onder nomen is te verstaan dat wat zich in de buitenwereld aan de waarneming voordoet, loopt ook vast: men denke bijv. aan de zgn. 'begriffliche Abstrakta'. De opvatting die hij met het voorbeeld $a b a k$ illustreert is voorts reeds niet te handhaven in gevallen die corresponderen met mal. pěrahu: bĕrpěrahu.

Toch liggen aan de traditionele classificatie nog andere principes ten grondslag dan alleen het genoemde. $\mathrm{Er}$ is ook een morfologisch principe: enerzijds verbuigbare of vervoegbare, anderzijds flectieloze woorden en een syntaktisch principe: kan een woord als dan niet subject zijn? Flexie of geen flexie: dit principe laat ons echter bij flextieloze of overwegend flectieloze talen in de steek. Over het syntaktisch gezichtspunt beneden nader. Paul ${ }^{2}$ ) heeft echter al geruime tijd geleden terecht opgemerkt, dat de traditionele tien woordsoorten en hun drieërlei indelingscriteria geen systeem vormen: de drie criteria staan onderling niet in hiërarchisch verband. Daaruit vloeit voort, dat er geen nauwer bijeen-behorende groepen van kategorieën onderscheiden worden. In bijzonderheden stelt deze ordening der schoolgrammatika ons voor zonderlinge consequenties: enerzijds onderscheidt men bijv. zelfstandige en bijvoegelijke naamwoorden, maar anderzijds geen zelfst. en bijv. tel- of voornaamwoorden, ofschoon deze eveneens op beiderlei wijs voorkomen.

Daarbij heeft men de moeilijkheden nog vermeerderd en beter inzicht nog meer belemmerd door bewust of onbewust naar een universeel systeem te streven. Zelfs Vendryes ${ }^{3}$ ) sticht op deze wijze verwarring. Wanneer hij de grammatikale hulpwoorden, die betrek-

1) Zie ook E. Sapir, Language, 1921, p. 123 vlgg.

2) H. Paul, Prinzipien der Sprachgeschichte ${ }^{5}, 1920$, hfdst. 20.

3) Vendryes, o.c., p. 137 vlg. 
kingen aanduiden buiten het woordsoorten-systeem wil laten, beroept hij zich op het feit, dat de rol die in de ene taal aan preposities toekomt in andere op geheel verschillende wijze vervuld wordt: fr. le livre de Pierre: lat. liber Petri. Maar men mag toch het Latijn of een conclusie op grond van een vergelijking met het Latijn niet als richtsnoer stellen voor de beoordeling van verschijnselen van deze aard in het Frans. En het feit, dat men in het Duits naast man sagte dasz der Graf gestorben ist (sei) kan zeggen man sagte der Graf sei gestorben mag ons niet doen besluiten, dat dasz geen woord is. Anders zou ook menig ander misbaar element onder die conclusie moeten vallen.

Ook de neiging tussen verschillende perioden uit dezelfde taal, waar nodig, niet te onderscheiden is een bron van misverstand geweest. Het is volstrekt niet gezegd, dat een taal in de loop harer geschiedenis dezelfde woordsoortenclassificatie vertoont, evenmin dat de definities der verschillende klassen eens en voor al gegeven zouden moeten zijn $^{1}$ ). De vraag wat de kenmerken van een werkwoord zijn heeft bijv. nog al wat stof doen opwaaien. Behoren daar de persoonsuitgangen toe? Maar in het Deens ontbreken deze en in het Engels ook bijna. Schleichers oplossing : ,werkwoorden zijn woorden die persoonsuitgangen hebben of gehad hebben" is onjuist, omdat we bij kwesties als deze iedere taal in een bepaalde periode tot object onzer beschouwingen moeten nemen; daartoe dwingt ons reeds een rustig bezien der feiten : in een bepaalde periode heeft een Germaanse taal wel, in een andere periode geen persoonsuitgangen, welnu: zoek voor beide perioden naar een eigen begripsbepaling van 'werkwoord' die er voor past, met behulp van gegevens die er in realiteit in aanwezig zijn. Uit Schleichers definitie zou bovendien volgen, dat we in een taal waarvan we niet zeker weten of ze ooit persoonsuitgangen gekend heeft, alleen daarom al niet van werkwoord kunnen spreken. De vraag welke de woordsoorten van het huidige Javaans zijn is er een van statische taalkunde, die men niet verwarre met historischdiachronische gezichtspunten. Ook Kern, in wiens tijd men nog niet tot dit inzicht was gekomen, begreep niet, dat het Javaans van 1000 jaar geleden in kwesties als deze geen maatstaf voor beoordeling van het huidige Javaans kan zijn. In zijn ${ }^{2}$ ) polemiek tegen Roorda ${ }^{3}$ ), die betoogd had, dat een en hetzelfde Javaanse woord de plaats kan in-

1) Tegen de eenzijdige structuralisten zou ik het belang van het diachronisch aspect uitdrukkelijk willen souligneren.

2) H. Kern, Verspr. Geschr. 4, p. 284 n.

3) T. Roorda, Javaansche Grammatica, 1855, § 99. 
nemen van een IdG. subst., adj. en verbum, bijv. lara ,ziek, ziekte, ziek zijn”, beriep hij zich ten onrechte op ojav. alara ,ziek” om de onjuistheid van Roorda's stelling aan te tonen. Hij vergiste zich, omdat hij niet inzag, dat de zaken in het Nieuw-Javaans anders kunnen liggen dan in het Oud-Javaans, evenals ze in de Romaanse talen in sommige opzichten anders liggen dan in het Latijn.

Genoeg!, men zou dikke delen kunnen vullen met kritiek op de opvattingen van vroegere en latere auteurs over de 'parts of speech'. Ik heb te minder aanleiding aan de gemaakte opmerkingen nog veel toe te voegen, omdat er in gemakkelijk toegankelijke werken velerlei kritiek te vinden is ${ }^{1}$ ). Sommige auteurs gaan in hun kritische houding zover, dat ze berustend overtuigd zijn geraakt van de onmogelijkheid het woord-materiaal van een taal op bevredigende wijze te classificeren. „It is impossible to set up a fully consistent scheme of parts of speech, because the word-classes overlap and cross each other", zegt Bloomfield ${ }^{2}$ ). En er zijn serieuze pogingen aangewend om een taal te beschrijven zonder een woordsoortenclassificatie.

Toch ontkomt men niet aan de indruk, dat sommige kritiek te ver gaat en dat er geleerden zijn, die te zeer neigen tot een ongemotiveerd skepticisme. Sapir ${ }^{3}$ ), wiens opvatting ik hier met modificaties en aanvullingen weergeef, wees er op, dat in een normale mededeling in de regel te onderscheiden is dat waarvan (waarover) men iets zegt en dat wat men er van zegt. Deze onderscheiding is blijkbaar van zodanig fundamenteel belang, dat de grote meerderheid van talen een of andere formele onderscheiding tussen beide kent. Het subject waarover de mededeling gaat is als regel een zelfst. nwwd. En daar de mededeling gewoonlijk gaat over dingen of personen, bestaat de meerderheid der substantieven uit aanduidingen van dingen of personen. En dat wat daarvan gepraediceerd wordt is in de regel een proces of een eigenschap, onder proces ook te verstaan een wijziging van status, van existentievorm, - en zo kan men zeggen, dat de kategorie van praedicaatswoorden vooral bestaat uit termen die processen of eigenschappen uitdrukken. Talen die deze onderscheiding op de een of andere wijze, min of meer, niet maken zijn er eigenlijk niet, betoogt Sapir.

1) Behalve de genoemde werken kan men bv. ook opslaan: O. Jespersen, The Philosophy of Grammar, 1924; idem, Analytic Syntax, 1937; L. Hjelmslev, Principes de grammaire générale, Kopenhagen 1928; V. Brøndal, Les parties du discours, Kopenhagen 1928.

2) L. Bloomfield, Language, ed. 1935, p. 196.

3) Sapir, o.c., p. 125 vlg. 
In het Yana, een Amerikaanse Indianentaal (West-Californië), wor den deze twee klassen toch onderscheiden, al hebben ze meer gemeen dan wij, gewend aan onze verschillen tussen subjects- en praedicaatswoorden, zouden verwachten of zelfs mogelijk achten. Maar andere parts of speech zijn er eigenlijk niet te onderkennen. Het blijkt zonder hen te gaan.

Bally ${ }^{1}$ ) maakte de belangrijke opmerking, dat de aanwezigheid van lexikale kategorieën door de zgn. transpositie bewezen wordt. Een lexikale entiteit kan met behoud van haar semantische waarde van grammatikale waarde veranderen door de functie aan te nemen van een kategorie waartoe ze van huis uit niet behoort ${ }^{2}$ ). Zo kan een substantief in een adjectief getransponeerd worden: fr. soleil: chaleur solaire, een adjectief in een substantief : het huis is hoog: de hoogte van het huis, een werkwoord in een substantief : veroveren: de verovering. In een taal als Frans of Nederlands ondergaat een subst. dat in een adj. getransponeerd wordt of een wwd. dat in een subst. getransponeerd wordt etc. formele wijzigingen. Daaruit blijkt, dat er wel degelijk klassen bestaan. We worden ons van hun bestaan bewust door de functionele transpositie. Deze klassen, de lexikale kategorieën, bestaan in de taal alleen als ze worden gekarakteriseerd door tekenen of kenmerken die tot de taal behoren. Ontbreekt ieder kenmerkend teken, dan kunnen ze in de reflecterende geest bestaan, maar dan behoren ze niet tot de taal. Men kan zo onder lexikale kategorieën verstaan de klassen van betekenisdragende taalelementen, die de ideeën uitdrukken, welke in het verloop van een taaluiting door middel van hen (d.w.z. de taalelementen) karakteriserende grammatikale elementen (uitgangen, suffixen, 'hulpwoorden', woordvolgorde etc.) gecombineerd worden (en die dus bij transpositie wijzigingen ondergaan in die grammatikale elementen). Bally komt er toe in het Frans vier grote klassen te onderscheiden - men denkt onwillekeurig aan Varro, de Arabische grammatici en in zekere zin aan de oude Indiërs -: subst. (cheval), adj. (chevalin), verbum (chevaucher), adverbium (à cheval).

Ook in het Maleis en andere IN. talen kunnen we transponeren: pandai: kĕpandaian; jav. rampasan; ṅampas etc. Kategorieën zijn er dus, maar is het mogelijk ze in een „fully consistent scheme” te brengen? Zij, die over de woordsoorten geschreven hebben, hebben

1) Bally, o.c., $\S 196$.

2) Men bedenke, dat Bally over Frans spreekt en zijn definities niet toetst aan andere talen behalve moderne Westerse. 
zich, met uitzondering van enkelen, zoals Sapir, weinig om niet-IdG. talen bekommerd, al brachten ze incidenteel het Chinees in discussie. Dit bestendigde de onjuiste overtuiging, dat ,het IdG. systeem” (ook reeds een fictie) op bijv. IN. talen van toepassing zou zijn. Vandaar de boven al gememoreerde traditie onder auteurs van IN. grammatika's aan de 10-delige school-classificatie vast te houden. De incidentele wijzigingen in detail waren daarbij evenmin van principieel belang als een verandering in terminologie. Dat volgens sommige auteurs Bataks, Malegasi, Soendaas geen adjectieven bezitten ${ }^{1}$ ), waarvan de functie dan door het werkwoord of het substantief zou worden waargenomen, terwijl van andere zijde voor het Javaans betoogd is, dat het geen werkwoorden kent ${ }^{2}$ ) - al deze discussie vindt haar uitgangspunt in het traditonele indelingssysteem. Wijziging van terminologie helpt niets en blijft een uitvlucht zolang men niet begrijpt, dat termen ook geinterpreteerd en gedefinieerd moeten worden in verband met de stof waarop men ze toepast. De terminologie is heus niet belangrijk. Er is niets tegen de traditionele te behouden, maar men dient nauwkeurig te weten wat men er van geval tot geval, d.w.z. van taal tot taal onder verstaat. De inhoud van de term verschilt naar gelang men spreekt over Grieks, Chinees, Maleis of Kwakiutl. Voor alles hoede men zich voor apriorismen, voor het vullen van van te voren aangenomen schema's met Maleis of andere IN. taalgoed.

Men beschouwe iedere taal op zichzelf en ieder harer ontwikkelingsstadia op zichzelf. Te veronderstellen, dat naverwante talen zich geheel eender zullen gedragen en dat men dus met het onderzoek van een hunner kan volstaan, leidt tot onjuist inzicht en mistekening der werkelijkheid. Vergelijking, na individueel onderzoek, van de leden ener taalfamilie is uiteraard zeer instructief. Daarbij zal blijken, dat nauwe historische (genetische) verwantschap geenszins uitsluit, dat een dezer na-verwanten met een derde meer overeenstemming in woordsoortenclassificatie en in transpositiemogelijkheden biedt dan andere. Het Engels, dat in transpositie zeer vrij is, staat hierin dichter bij het Frans dan bij het Duits.

Een ander principe bij het onderzoek moet zijn, dat lexikale entiteiten, die onder alle omstandigheden hetzelfde gedrag vertonen bijeen behoren. Een volgend, dat, waar normale taal uit zinnen en

1) Zie H. N. van der Tuuk, Tobasche Spraakkunst, 1867, p. 94 onder; S. Coolsma, Soendaneesch-Hollandsch Woordenboek ${ }^{3}$, p. XVII.

2) C. C. Berg, Inleiding tot de studie van het Oud-Javaansch, 1928, p. 202. 
niet uit losse woorden bestaat, niet deze op zich, maar de zin tot grondslag van onze onderzoekingen moet worden genomen.

Willen we nu enige beschouwingen wijden aan de classificatie der lexikale entiteiten in het Maleis, dan dienen we als hoofddoel daarbij de beantwoording van deze vragen voor ogen te stellen: laat het Maleis een restloze indeling van zijn woordmateriaal toe? d.w.z. bestaat er in het Maleis een bepaalde classificatie van het gehele woordmateriaal? En zo ja, waarop, op welke principes berust die classificatie?

Een discussie over de indelingsprincipes vinden we in Jespersens Philosophy of Grammar ${ }^{1}$ ), waar de vraag wordt opgeworpen hoe in te delen is, naar vorm, naar syntaktisch gedrag, naar betekenis. „In my opinion”, zegt de Deense geleerde, ,everything should be kept in view, form, function, and meaning, but it should be particularly emphasized that form, which is the most obvious test, may lead to our recognizing some word-classes in one language which are not distinct classes in other languages, and that meaning, though very important, is most difficult to deal with, and especially that it is not possible to base a classification on short and easily applicable definitions". Inderdaad, een indeling naar vorm geeft het meeste, een naar betekenis het minste houvast. Maar als men deze drie indelingsprincipes weliswaar in verschillende mate doelmatig acht, doch overigens gelijkwaardig, blijft men in moeilijkheden.

Een feit is, dat ook in het Maleis een indeling op grond van het formele principe mogelijk is. De vraag is alleen, of ze bevredigt. Immers men kan alle woorden met bĕr-, met $m \breve{e}$-, met těr - in afzonderlijke groepen brengen en deze zelfs met enige andere groepen onder het hoofd werkwoord verenigen, en anderzijds de woorden

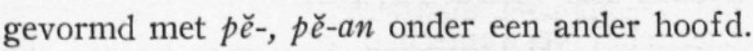

Het valt dan niet te ontkennen, dat het affixenstelsel toch tot op zekere hoogte een indeling in woordsoorten aan de hand doet. In het Maleis zijn bijv. de woorden met het praefix p $\breve{e}-$, al of niet vergezeld van het suffix -an, door hun betekenis en syntaktische positie als substantiva gekenmerkt: datañlah pěnulú dari pada Tuhan ,er is hulp gekomen van God”; oraì itu gaiblah daripada pěmandañannya „de man verdween uit hun gezicht". Uit de aard der zaak komen gevallen van transpositie in een adjectief voor of gevallen waarin een woord gelijkwaardig met een adjectief optreedt: sañat ${ }^{\mathrm{C}}$ adil lagi pěmurah

1) O. Jespersen, The Philosophy of Grammar, p. 60 . 
(Indera Bangsawan p. 3). Zo vormen in het Madoerees pa-, pa*-, pè-, par-, pa-an substantiva. Het suffix -an doet dit ook: tabbhuwan „muziekinstrument”, maar dit vormt ook adjectieven: baialan „,moedig”; takòdhan „vreesachtig”. In het Javaans is sukětan „een grasland”, (éreru-an >) éron ,bij duizenden”, rěmbugan ,gezamenlijk overleggen". En zo staat het in Maleis, Madoerees en elders bijv. ook met de ka-an vormen. Woorden met kĕ-an, bijv. kĕběsaran en kĕpanasan, kunnen zich in het Maleis geheel verschillend gedragen, en andersom woorden met formeel verschil geheel eender. Het affixenstelsel leidt ons niet tot een indeling van het volledige woordmateriaal; er zijn vele woorden zonder affix en er zijn verscheiden formele kategorieën van woorden gevormd met hetzelfde affix, maar met verschillende functie en syntaktische valentie. Toch zijn grondwoorden in het algemeen overwegend substantiva: op 8 willekeurige bladzijden van Van Ronkels Maleis Woordenboek telde ik, leenwoorden, onomatopeeën etc. buiten beschouwing gelaten, \pm 145 grondwoordelijke subst., \pm 65 adj. en verba en 4 die beide kunnen zijn; op een aantal willekeurig gekozen bladzijden uit de Indera Bangsawan is de verhouding substantivische en verbaal-adjectivische grondwoorden $\pm 4: 1$. En voor andere IN. talen is het aantal uitsluitend adjectivische grondwoorden eveneens relatief gering.

Men kan op deze wijze dus tot een classificatie komen, maar deze bevredigt niet als woordsoorten-classificatie ${ }^{1}$ ). Men kan echter opmerken, dat het formele criterium de indruk maakt fundamenteel te zijn, en wel daarom, omdat in de taal in het algemeen formele classificaties van fundamentele realiteit zijn. Hoe is een morfologisch systeem geordend? Niet naar onderscheiding in genus en species, maar naar een zeker cumulatief principe, waarin, om de terminologie van De Groot te bezigen, kernelementen en meer perifere elementen onderscheiden worden : het in de vormen van het Latijnse werkwoord amare (zo goed als) steeds aanwezige ama- draagt de algemene betekenis „beminnen”: -vi, -bam, -tur, $-s$, $-t$ etc. brengen modificaties aan. Deze modificaties kunnen van verschillende aard zijn, in verschillende kategorie thuishoren: de een brengt de werkwoordsvorm in een bepaalde tijd, de ander in een bepaalde modus, een derde in een bepaald verbaal genus; ze kunnen zelfs in meer dan een kategorie tegelijk brengen: skt. $e$-dhi representeert $2 \mathrm{e}$ persoon enkelvoud imperativi

1) Zie hierbij en bij het volgende ook A. W. de Groot, Structural linguistics and word classes, in: Lingua I (1948), p. 427 sqq. 
praesentis activi. Ook een IN. taal kent in zijn woordvormingssysteem ditzelfde ordeningsprincipe: in mal. kĕras „geweldig”, měněrasi „,iemand geweld aandoen”, měñ̌raskan ,iets met geweld doen”, pěněras „middel om geweld te gebruiken” steekt telkens als 'kern' kěras ,geweld” en de perifere elementen komen ieder, op systematische wijze, in tal van andere woorden voor.

$\mathrm{Nu}$ kan men, waar dit alles in de taal van een zo evidente realiteit is, trachten verder te gaan dan Jespersen en trachten het morfologische criterium ook primair te stellen bij de classificatie der woordsoorten. Zo kan men pogen deze classificatie te zien als een reductie van het morfologisch systeem tot een hogere systematisering met minder kategorieën ${ }^{1}$ ). In een taal als het Nederlands kan men op grond van het morfologisch classificatie-principe komen tot bijv. een klasse der werkwoorden, een der zelfst. naamwoorden, een der eigennamen (morfologisch verschil met de vorige klasse: geen meervoud, en genitief: het dak van het huis: Jans vader) etc., die samen de hogere klasse der verbuigbaren uitmaken en tot klassen als voegwoorden, bijwoorden etc., die samen de hogere klasse der onverbuigbaren vormen. Zeer ver doorvoerbaar is dit classificatieprincipe in het Sanskrit en de Indische grammatici hebben er dan ook dankbaar gebruik van gemaakt. De overgrote meerderheid der woorden in het Sanskrit is duidelijk gebouwd volgens het cumulatieve principe: wortel + suffix. En de suffixen vallen even duidelijk uiteen in verbale en nominale, duidelijk ook omdat de eerste door verbale uitgangen, de tweede door casus-uitgangen gevolgd worden: tuș-ya-te: tus-ti- $i$ bhis. Daarnaast bestaat een groep onverbuigbaren, die vaak door hun korte vorm opvallen: $d h i k$ !, $h i, c a$. Weliswaar zijn er enkele wortelwoorden (nomina), maar die hebben in het kader van de nominale morfologie suffix nul, alleen de nominale uitgangen. De grammatici hebben deze, in de taal zo evident bestaande, formele onderscheiding dan ook gezien en verbale vormen $(\text { kriyā })^{2}$ ), nominale vormen (nāman) en indeclinabilia ${ }^{3}$ ) onderkend. Waar het morfologisch criterium aanmerkelijk minder duidelijk is, zijn ook de grammatici minder stellig: tussen adjectief en substantief is het formele verschil veel geringer dan tussen de bovengenoemde kategorieën (tal van adjectieven kunnen substantivisch optreden, vaak heeft een suffix zowel

1) Zie ook De Groot, o.c., p. 433 sqq.

2) Met inbegrip evenwel van de nominale verbaal-vormen als infinitief, participia etc.

3) De infinitief is echter ook indeclinabel! 
adjectivische als substantivische waarde: kampana-,,bevend; beving”), en de grammatici bepalen deze klassen, al hebben ze ook termen die op formele eigenaardigheden van het adjectief slaan, in onderlinge correlatie, op grond van hun syntaktische verhouding: viśeșana „kwalificerend woord” (adj.) en viśeșya „(nomen) dat te kwalificeren is" (subst.).

Wil men echter ten aanzien van het Maleis deze weg bewandelen, dan komt men tot een minder bevredigend resultaat. Stelt men nl. enerzijds alle woorden die steeds in dezelfde vorm voorkomen tegenover anderzijds alles wat formele variabiliteit vertoont, dan moet men lëmbu ,rund”, tiba ,aankomen”, tidak „niet” in dezelfde klasse opnemen tegenover ( $k u$-, kau-, měm-) běri en dergelijke ${ }^{1}$ ). En een classificatie van afgeleide woorden aan de ene kant tegenover grondwoorden zou kĕdiaman „woonplaats”, mĕlainkan „slechts”, bĕrlutut „knielen”, měmbaiki ,herstellen” bij elkaar brengen en scheiden van rumah „huis”, jua ,slechts”, tunduk ,buigen” etc. ${ }^{2}$ ).

Hier stuiten we op het oude probleem van de zgn. grondwoorden en afgeleide woorden: tidur naast berrlutut. Ik herinner mij eens een docent in een IN. taal een betoog te hebben horen houden over de vraag in welke woordsoort grondwoorden als mal. tidur op te nemen zijn: tidur en derg., zo was zijn standpunt, zijn werkwoorden te noemen al is ,slapen” dan geen werken, omdat lichamelijke bezigheid

1) Een dergelijke opmerking bij Jespersen, o.c., p. 60 naar aanleiding van Eng. must, 'indeclinabel' evenals the, then, for.

${ }^{2}$ ) Het Maleis en andere IN. talen kennen geen stammen van het type als de historische grammatika van Latijn of Sanskrit die onderscheidt, onder 'stam' te verstaan het predesinentiële element (het element vóór de uitgang), d.w.z. de wortel plus het suffix (al kan het laatste nul zijn), 'stam' als element dat de betekenis van het woord op zich draagt. Alleen voor het type -pukul in $k u$-, kau-pukul etc. zou men een uitzondering kunnen maken. Bij een synchronische definitie van 'stam' als door De Groot gegeven (cf. Lingua I, p. 442) (,the stem is the most central, sometimes the only, morpheme of a word" waarbij 'central' als volgt omschreven wordt: ,when in a certain function, in this case as 'word', an element a, and also the combination a $+b$, but not $\mathrm{b}$ without a can be used, we call the element $\mathrm{a}$ in the combination $\mathrm{a}+\mathrm{b}$ more central than the element b") valt in het Maleis, afgezien ook weer van de zg. vervoegde vormen, het begrip 'stam' met het begrip 'woord' samen. Noemt men pukul in ku-pukul echter 'stam', dan verdient het aanbeveling mĕmukul niet eveneens een 'stam' te noemen, wat het gezien naast pěmukul, eveneens cen 'stam', aan de andere kant wel is. Men doet m.i. het beste de term 'stam' in IN. talen niet te bezigen, tenzij desnoods voor het grondwoordelijke element in de vervoegde vormen, en van 'woord' te spreken.

D1. 105 . 
en gedrag in ruime zin, dus ook standen, houdingen etc. als een zekere activiteit gezien kunnen worden. Hetzelfde geldt dan bij enige uitbreiding ook van mati etc. Sommigen hebben zich grote moeite gegeven om de eerst geschapen moeilijkheden te ontwarren. De Hollander ${ }^{1}$ ) bijv. weidt er over uit, dat sakit niet alleen ,ziek”, maar ook „ziek zijn, -worden” en ,ziekte” betekent. En Pijnappel ${ }^{2}$ ) verdedigde het standpunt, dat alle woorden in het Maleis oorspronkelijk een ,iets zijn” betekenen : kuda is eigenlijk ,paard zijn”. Er is over gefilosofeerd, of in ,hij voelt honger" het subject al of niet een handeling verricht, of in oran itu lapar lapar al of niet een werkwoord is. Zo vraagt Tendeloo ${ }^{3}$ ) zich af, waarom het wel een handeling is als men van zijn gehoor- of gezichtszintuig gebruik maakt, maar niet als men zijn gevoelszenuwen laat werken. Dit alles, omdat men gebiologeerd is door de bijkomstige omstandigheid, dat deze woordsoort in het Nederlands werkwoord heet. Maar de Duitsers zeggen Zeitwort! Overbodig te zeggen, dat het evenzeer onjuist is met H. Kern ${ }^{4}$ ) te concluderen, dat woorden waarin geen tijdsbetrekking ligt opgesloten per se geen werkwoorden kunnen heten, omdat het begrip van tijd onafscheidelijk met dat van het werkwoord verbonden zou zijn. Romeinse, Franse en Engelse geleerden, die van verbum etc. „het woord (bij uitnemendheid)" spreken, hebben het niet nodig gevonden het werken of de tijd in hun term op te nemen. Al deze discussies op grond van een letterlijke interpretatie van de term kunnen we laten voor wat ze zijn: overbodig en onjuist. Het minst tot misverstand zou aanleiding geven een terminologie met cijfers en letters: A is de betekenis van woordsoort 1 . Wil men daar niet aan, dan kan men zich behelpen met formuleringen als : een zelfst. naamwoord is een woord dat een substantie uitdrukt, een verbum (werkwoord) een dat een proces uitdrukt en uitdrukken van een proces is de 'betekenis' van een werkwoord. Waarbij men zich bewust moet blijven $1^{\circ}$ daarvan dat substantie etc. niet steeds samenvallen met wat in andere wetenschappen daaronder verstaan wordt en $2^{\circ}$ dat men de woordsoorten werkwoord etc. door andere, natuurlijk taalkundige,

1) J. J. de Hollander, Handleiding bij de beoefening der Maleische Taal en Letterkunde ${ }^{6}, 1893$, p. 48 vlg.

2) J. Pijnappel, Maleische Spraakkunst, p. 34 en 37.

3) H. J. E. Tendeloo, Maleische verba en nomina verbalia, Diss. Leiden 1895, p. 147 , n. 1.

4) H. Kern, Verspreide Geschriften, 8, p. 201. 
criteria nader moet zien te bepalen. Jespersen had gelijk: „meaning, though very important, is most difficult to deal with" ${ }^{1}$ ).

Neen, àls bijv. tidur zich onder alle omstandigheden eender zou gedragen als bijv. měnaniis en we noemen měnanis een werkwoord, dan moeten we ook tidur een werkwoord noemen. Zoals we ook in de morfologie bij lat. puellae in het ene syntaktische verband van een datief sing., in het andere van een genitief sing. of een nominatief plur. spreken, op grond van de formele onderscheiding van uxori, uxoris, uxores en vele andere woorden, waar drie (formele) naamvallen met eigen functie aanwezig zijn.

Dit brengt ons op het criterium van het syntaktisch gedrag. Wat tidur op zichzelf, buiten alle verband is, is niet te zeggen. In saya tidur gedraagt het zich syntaktisch als měnaniis in saya měnanis, in tidurku als bapa in bapaku. M.a.w. dergelijke grondwoorden kunnen in de ene syntaktische verbinding de ene, in de andere een andere waarde hebben. In saya tidur is tidur een procesuitdrukkend woord, in tidurku een substantieuitdrukkend. Nu kan men de vraag opwerpen, of hier van die transpositie sprake is die men hypostase noemt: die soort transpositie, waarin de kategorie waarin het woord geplaatst wordt niet door formele kenmerken wordt onderscheiden, maar alleen door syntaktische valentie: bijv.fr.des manières enfant, waarin enfant als adj. optreedt, eng. a master stroke, a boy king. Wanneer het geval niet zo ligt, dat tidur normaal bijna steeds hetzij verbale, hetzij substantivische valentie heeft, zou ik er niet voor zijn in de inciden-

1) Onder woorden die een proces uitdrukken rekenen we dus niet alleen de ten opzichte van hun betekenis zg. energetische werkwoorden (dwz. die waarbij in het algemeen subject is een persoon of als zodanig beschouwd wezen of grootheid, wiens of welks wil een beslissende rol speelt, en die transitief of intransitief zijn, onder de transitieve ook gerekend de $\mathrm{zg}$. autarke, die geen object behoeven, als drinken, nl. drank), maar ook de verba van anenergetische betekenis, waarvan twee groepen te onderscheiden zijn, zij die toestanden aanduiden, zoals liggen, zwijgen, denderen (verba stativa) en zij die een overgang van de ene toestand in een andere uitdrukken (metastatische werkwoorden): opstaan, vallen, sterven, verdrinken (het proces geschiedt of met of zonder, resp. tegen de wil van het subject). De statieve en metastatische werkwoorden zijn intransitief. Uiteraard zijn er verba die onder omstandigheden in de ene of andere kategorie optreden: skt. tișthati „staan” (statief) en „blijven (stil)staan, gaan staan" (metastatisch); een werkwoord als zwijgen kan ook aanduiden, dat men van spreken in niet-spreken overgaat etc. Ook kan een werkwoord dat gewoonlijk anenergetisch is onder omstandigheden energetisch zijn: skt. patati „vallen”, soms: „,zich storten (op, voor), zich laten vallen”. Bij de beschrijving van IN. talen heeft men, tot schade van een juist begrip, deze onderscheidingen vaak verwaarloosd, zo bv. wanneer men de vaak metastatische -um-vormen in het Javaans „toestandswoorden" noemt. 
tele gevallen van het tegendeel de term hypostase te gebruiken. Bij tal van IN. woorden van dit grondwoordelijke type is er geen ander criterium dan de syntaktische verbinding. En dit wijst uit, dat ze nu eens fungeren als wat men verbum, dan weer als wat men - we komen er op terug - substantief kan noemen. Hier zijn we dus tot de syntaktische waarde als criterium gekomen.

Keren we nog tot het formele criterium terug. Het IN. morfologische systeem vertoont belangrijke verschillen met dat van Latijn of Sanskrit, een punt dat we hier niet in den brede kunnen bespreken. Het is overwegend een woordvormingssysteem. Latijn etc. kennen een stamvormings- naast een flexiesysteem ${ }^{1}$ ). IN. talen hebben daartegenover, van de 'vervoegde werkwoordsvormen' afgezien, één woordvormingssysteem met affixen. Deze affixen corresponderen soms met IdG. flexieuitgangen (ojav. pa-turu : skt. svapi-hi ,slaap”, mal. oran் itu měnanami sawah, waar in een taal die die naamval heeft sawah met een locatief weergegeven kan worden), soms met affixen,

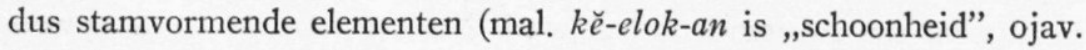
pa-takwan ,de vraag” en mal. měnanami correspondeert óók met ned. be-planten). Naast het type měnanami staat měnanamkan met, in het algemeen, het bekende verschil. Zowel $-i$ als $-k a n$-vormen zijn als regel transitief, maar laten ieder slechts een bepaalde kategorie van objecten toe, kort gezegd zgn. locale of instrumentale. Overeenkomstige verschijnselen vindt men, gelijk bekend, in IN. talen in het algemeen. IN. talen hebben dus, in het algemeen gesproken, een relatieve rijkdom van formaties op het stuk van transitiva.

Ze zijn evenmin, relatief gesproken, arm aan zinsvormen, d.w.z. aan dat wat Bloomfield ${ }^{2}$ ) 'favorite sentence-forms' noemt. Heeft het Engels daarvan slechts twee: de actor-action constructie John ran away en het bevel-type come!, in het Latijn bestaat het eerste, het 'narratieve' type in twee variëteiten homo amat en homo amatur en komt daarnaast nog het 'werkwoordloze' 'equational' type beatus ille voor. Het Maleis kent dit laatste type: saya sakit, oran itu gila, een type saya mĕmbuka pintu itu; saya mĕnanami sawah; saya měnikamkan kĕris, maar daarnaast nog de variëteit pintu itu kubuka of kubuka pintu itu (saya buka p.i.), waarbij pintu dibuka(nya). Daarnaast nog een 'imperatief' type: ... suruh bĕrjaga!; pĕrgi(lah). Met vertegen-

1) Ter oriëntering zie men bv. A. Meillet, Introduction à l'étude comparative des langues indo-européennes ${ }^{8}$, Parijs 1937, p. 146 vlg.

$\left.{ }^{2}\right)$ L. Bloomfield, Language, ed. 1935, ch. 11. 
woordigers van deze zinsvormen, al of niet aangevuld met andere woorden, hebben we in het Maleis, in het algemeen, te werken.

Men kan er lang of kort over spreken: er is in het Maleis te weinig flexie om deze met kans op succes tot het voornaamste criterium te maken bij een poging zijn 'parts of speech' vast te stellen. Er is slechts één kategorie waarbij men van flectie kan spreken, die der zgn. vervoegde werkwoordsvormen in de zinsvorm pintu itu kubuka.

Maar hier te blijven staan en slechts twee 'parts of speech' te onderscheiden: "inflected and uninflected words" ${ }^{1}$ ) dat zou hoogst onbevredigend zijn.

Een ding is echter hier al duidelijk: dat we voldoende recht hebben in het Maleis een kategorie te onderkennen, waaraan we m.i. zonder bezwaar de naam verbum (werkwoord, zonder iets verkeerds bij werk- te denken!) kunnen geven ${ }^{2}$ ). Mits we bedenken, dat een Maleis verbum in vele opzichten van een Nederlands of Latijns verbum kan afwijken, in vele, ja in zeer fundamentele punten. Het type kubuka, saya buka heeft opvallende kenmerken. Andere praefixen, als mě-, těr $r$ - etc. treden er niet bij op, ook geen possessieve suffixen. De beide componenten, waarin kubuka of saya buka geanalyseerd kunnen worden, zijn onscheidbaar. kubuka is zelf een complex woord, d.w.z. het bevat een 'bound form' (d.i. een deel van een uiting dat nooit op zich zelf mèt een betekenis voorkomt: in casu $\left.k u-{ }^{3}\right)$ ). De complexe vorm die het praefix bevat, dat, in correlatie met de pronomina - we bezigen deze term vooruitlopend op een later deel van deze beschouwingen - grammatikale personen aanduidt, drukt een proces uit. "Words inflected for person, number, tense, mood, and voice are called verbs": in het Latijn, maar het is stellig niet gezegd, dat al deze kategorieën aanwezig moeten zijn om van een verbum te spreken.

De hierboven gereleveerde twijfel of in het Javaans eigenlijk wel werkwoorden bestaan lijkt mij derhalve niet gerechtvaardigd. Het argument dat, onder meer, tot deze twijfel aanleiding gaf, zal men m.i. niet kunnen handhaven: ,genasaleerde vormen kunnen wij in het Hollands even vaak met zelfstandige of bijvoeglijke naamwoorden als met werkwoorden weergeven". Ten eerste valt de kategorie der

1) Zie B. Bloch and G. L. Trager, Outline of linguistic analysis, Ling. Soc. of America, Baltimore Md. 1942, 4.6 (p. 60).

2) Terecht zeggen Bloch en Trager, 1.c. dat de terminologie niet belangrijk is, even terecht dat men liever niet voor iedere taal een eigen terminologie moet scheppen.

3) Over deze terminologie Bloomfield, o.c., p. 160 vlgg. en Bloch en Trager, o.c., p. 54. 
genasaleerde vormen geenszins samen met de veel ruimere groep van vormen die men in het Javaans en verwante talen werkwoorden pleegt te noemen, en voorts kan een wijze van vertalen in een andere taal - en dat nog wel in een taal van zeer afwijkende structuur - geen criterium zijn. Geven wij, in het Nederlands vertalende, soms ook niet termen uit Europese talen met een zelfstandig naamwoord weer, die in hun eigen taal tot een andere woordsoort gerekend worden?: lat. ab urbe condita ,na de stichting der stad" (vgl. ook it. La Gerusalemme liberata). Zijn niet tal van participia als substantief in gebruik gekomen : protestant; manifestant etc.; zijn, in onze eigen taal, adjectiva en adverbia als razend, ontzettend van oorsprong geen participia, is skt. sissya, dat wij met een substantief vertalen (,leerling”), van huis uit geen gerundivum? - Een argument tegen de zienswijze, dat men vormen als o.jav. nanis, turu, lumaku, mal. měnainis, tidur etc. als adjectiva kan opvatten ligt voorts, gelijk we verderop betogen, in het verschil in syntaktische verbindbaarheid: men kan bijv. wel zeggen oran tua itu tidur, maar niet orá tidur itu tua; evenmin kan men zonder meer vervoegde werkwoordsvormen attributief bezigen. Er zijn voorts ('adjectivische') grondwoorden, waarvan men geen afleidingen kan vormen met 'verbale' affixen: ku-tua, mĕnua etc. bestaan in het Maleis niet. - Verwarrend is ook, dat men, ten onrechte, vervoeging op IdG. wijze noodzakelijk achtte om van ,werkwoord” te kunnen spreken: buiten het vervoegde, finiete werkwoord, de persoonlijke vormen, kent het IdG. verbum nog vormen waaraan de persoon niet is uitgedrukt.

De vormen kubuka etc. laten zich echter niet wel van mĕmbuka scheiden. kubuka etc. zijn niet de enige kategorie die een proces uitdrukt. Naast saya buka pintu itu staat saya měmbuka p.i. In deze twee zinnen zijn buka en mĕmbuka syntaktisch gelijkwaardig. saya měmbuka is echter niet een onscheidbare verbinding: $s$. tidak m., tegenover tidak s. b. ; in een vragende zin is bij gebruik van $m$. inversie mogelijk. Beide vormen laten op dezelfde wijze transpositie toe:

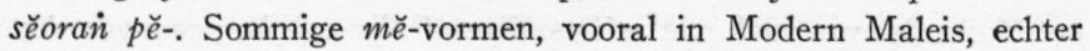
ook hypostase: měnurut pikiran saya ia akan kĕmbali. Er komt echter meer bij: een aanmerkelijk verschil tussen de $m \breve{e}$-vorm enerzijds en de vervoegde e.a. vormen anderzijds is dat de eerste 'head'-woord ${ }^{1}$ ) kan zijn, d.w.z. kern van een syntaktische groep: měněrjakan் luban் itu sampai sudahnya lima hari, en geheel en al kan fungeren als ieder

1) Voor deze term zie Bloch en Trager, o.c., p. 76 en De Groot, o.c., p. 437. 
ander woord dat door $i t u$ kan worden bepaald. Ook is een deel der $m \breve{e}$-vormen intransitief, wat met de vervoegde vormen nooit het geval is, - een bijzonderheid van de soort die men in andere talen bij pogingen om het woordmateriaal te classificeren gewoonlijk verwaarloost en waarbij auteurs van Maleise spraakkunsten nauwelijks stilstaan. Toch is het onderscheid gewichtig. Een deel der $m \breve{e}$-vormen is transitief, evenals alle mĕ-i en mě-kan vormen, - iets wat uiteraard absoluut (objectsloos) gebruik niet verhindert. Het type pukulměmukul ,elkaar slaan” kan men autark noemen. De intransitieve en autarke hebben geen vervoegde en $d i$-vormen naast zich, de transitieve wel. Men doet goed dit onderscheid niet te verwaarlozen ${ }^{1}$ ). Immers, -buka (měmbuka), -pukul (měmukul) etc. enerzijds, měnyěbĕran், měnyělimpat etc. anderzijds vormen twee verschillende groepen van woorden, evenals in het Latijn de intransitieve, transitieve (tevens verba sentiendi et declarandi), overige transitieve en impersonale werkwoorden afzonderlijke, onderscheiden groepen van verbale stammen vormen. Al kunnen zich in een taal met een dergelijke groepering uiteraard 'bijzondere gevallen' voordoen: verba die transitief èn intransitief kunnen zijn. De stam van het type $d i$-, $k u$-pukul: měmukul, n.l. - pukul (enzovoorts: -lihat, -buka etc.) vindt men ook als woord gebruikt, in de imperatief: bawa pěti itu!; minyaki rambutmu!; lëpaskan oran் itu! Hier is, uiteraard, formele overeenstemming met de werkwoordelijk gebruikte grondwoorden bij de uitdrukking van een gebod: duduk!; pĕrgi! De intransitieve $m \breve{e}$-vormen echter behouden ook bij een gebodsuitdrukking mě-: měněpi! Tot de bijzondere gevallen zou men ook kunnen rekenen de voorzetselverbindingen bij intransitieve werkwoorden: měnumpaì dalam kapal, de aanwezigheid of toelaatbaarheid van voorzetselverbinding naast direct object ${ }^{2}$ ), zoals in měnanami sawah děnan padi, mĕnanamkan padi disawah. Zoals ik het thans zie, lijkt me het beste te zeggen: de vervoegde vormen, de grondwoordelijke vormen (bawa...!), de divormen zijn geen woordsoortkategorie naast en gelijkwaardig aan de $m \breve{e}$-vormen, maar een flexie-kategorie, een morfologische kategorie ${ }^{3}$ ).

1) De Groot (o.c., p. 450 en 481) onderscheidt ook de Latijnse verba met accusativus cum infinitivo van de transitieve verba die niet zijn verba sentiendi en declarandi en de Nederlandse werkwoorden die dat na zich krijgen van die welke door of gevolgd worden.

2) Uitdrukking van het object zonder voorzetsel.

3) Zie thans ook De Groot, o.c. p. 457: „A morphological system, e.g. the verbal system of Latin, is distinguished from a word class system by the fact that it does not contain all the words of a given language, but only a special collection to the exclusion of all others." 
De $m \breve{e}$-vormen vallen uiteen in transitiva, waarnaast nog een paar reeksen staan, en intransitiva, waarnaast dergelijke reeksen niet aanwezig zijn. De vervoegde vormen etc. zijn bepaalde verschijningsvormen van transitieve werkwoorden. De $d i$-vormen hebben een syntaktische eigenaardigheid: ze kunnen vergezeld worden door een uitdrukking van de agens, al of niet voorafgegaan door oleh ${ }^{1}$ ). Ze gedragen zich dus syntaktisch anders dan $k u$-vormen etc. en $m e$-vormen.

Terloops mag worden opgemerkt, dat in andere IN. talen andere scheidingslijnen kunnen lopen. In het Bare'e is een deel der mavormen ( $m a-\mathrm{II}$ van Adriani) intransitief, evenals $m e-$, pe-, mo-, povormen e.a., een ander deel van de $m a$-vormen (ma-I van Adriani), de vervoegde vormen e.a. transitief.

Komen we thans tot dat element van de zin waarover iets gezegd wordt, het subject. Er is in het Maleis een groep lexikale entiteiten, grondwoorden, maar daarnaast ook andere, die zich met pronominale suffixen laten verbinden (bapa-nya), die door itu, ini kunnen worden gevolgd en bepaald (saudagar itu) en, speciaal in het klassieke Maleis, op zichzelf niet telbaar zijn, doch met hulptelwoorden geteld worden: sěekor kuda ${ }^{2}$ ). Deze woorden kunnen als head optreden, ze treden niet attributief op, attributief in de zin waarin Engelse boeken deze term plegen te gebruiken: adjunct, adherent: adjectief employé en fonction d'épithète ${ }^{3}$ ) (als mooi in: een mooi huis). Ze kunnen, als subject, en als object van de zin fungeren. Ze worden, evenals de zelfstandige pronomina, door bukan ontkend: běndahara itu datan bukan waktunya; bukanlah aku ini raja 'alam; saya bukan guru, terwijl een niet-substantief in het algemeen door tidak, tiada genegeerd wordt: rumah itu tidak běsar, ... dijual; al zijn hiermee de functies van bukan niet uitgeput ${ }^{4}$ ). Deze woorden, die we substantief kunnen noemen, laten zich zelf in het algemeen wel attributief bepalen (rumah tingi). Ze kunnen - waarover beneden nader - een praepositie voor zich krijgen. $\mathrm{Er}$ is geen reden om die substantiva die door hun betekenis het kenmerk der telbaarheid missen en geen verdubbelde vorm toelaten, van deze groep uit te sluiten; kĕsopanan ,ingetogenheid”, loba ,inhaligheid”. Zou men dit doen, dan moeten ook maat-

1) Oleh kan ook bij grondwoordelijke verba e.a. optreden.

2) Over dit laatste mijn opmerkingen: Het Maleise nomen en de numeruskategorie, Bijdragen 98 , p. 371 vlgg.

3) Marouzeau, Lexique de la terminologie linguistique, 1933, p. 38.

4) Men denke bv. aan het corrigerende bukan voor adjectief na een vraag van tegengestelde strekking. 
woorden als jěrikal, rupiah, jurus, die zonder meer met telwoorden verbonden worden, in het klassieke Maleis als afzonderlijke groep gelden.

In allerlei talen vormen de eigennamen een eigen kategorie, al brengt de traditionele taalbeschouwing ze onder één hoofd. In IdG. talen bv. treedt de vocatief praktisch alleen bij eigennamen ${ }^{1}$ ) op; ze hebben, in het normale geval, geen pluralis; ze hebben in het Nederlands, van enkele oude wendingen bij substantiva afgezien, bij uitsluiting, een genitief (Jans vader). Maar dit laatste geldt eigenlijk niet van alle eigennamen; bij namen van bergen en rivieren ken ik geen genitief. In het Maleis zijn alle eigennamen gekenmerkt doordat ze niet telbaar zijn, niet verdubbeld worden en zich niet met pronominale affixen laten verbinden; de persoonsnamen vormen echter een afzonderlijke groep: ze dulden, als regel, bepaalde pronomina niet voor zich:kĕpada leidt de persoon in naar wie een subject zich beweegt etc.: pĕrgi kĕpada tuan putěri, niet kĕ, en zo daripada en niet dari. Daarbij kunnen ze door een zg. persoonswijzer of persoonlijk lidwoord ${ }^{2}$ ) geintroduceerd worden : si Ali, san Boma, al kan si, dat karakteriseert of releveert, ook treden voor bepaalde substantiva (als in si pěncuri, ,d(i)e dief”), die bepaalde personen aanduiden ${ }^{3}$ ); men vergelijke daarbij overeenkomstige verschijnselen in andere IN.talen : in het Bimanees ${ }^{4}$ ) „worden eigennamen van personen aangeduid door $l a \ldots$., dat ook ,woorden die niet als naam gebruikelijk zijn en zelfs gehele uitdrukkingen tot eigennamen" maken kan, zoals Jonker het uitdrukt. Andere Maleise eigennamen hebben, anders dan de persoonsnamen, vaak classificatoren bij zich: suñai Jambi, nĕgĕri Bĕlanda etc.; ze naderen daarmee die substantiva die door een genusuitdrukkende classificator voorafgegaan worden: type buia mělur.

Wat dit laatstgenoemde voorbeeld aangaat, men kan dit als samenkoppeling van een geijkt type beschouwen en in zijn geheel als substantief classificeren. Dit brengt ons op de zg. hulptelwoorden: ekor in anjin tiga ekor. In dergelijke verbindingen missen ekor en de andere numeratieven of classificatoren mogelijkheden die ze, op zich zelf gebruikt - ekor als ,staart”, atap als ,dak”, orain als „mens” -

1) Afgezien van sommige die in hun betekenis tot eigennamen naderen: vader, zus, kind, vriend etc.

2) Zie Bijdragen, dl. 102 , p. 510 vlgg.

${ }^{3}$ ) Enige details bv. bij R. J. Wilkinson, A Malay-English Dictionary, II (1932), p. 466.

4) J. C. G. Jonker, Bimaneesche Spraakkunst, § 190. 
bezitten. M.a.w. als „staart” is ekor substantief, als hulptelwoord gedraagt het zich afwijkend. Het is bv. in het klassiek Maleis zonder meer met een telwoord te verbinden, duldt geen poss. pron. suffix. Maar met een telwoord verbonden vormt het geen volledig 'begrip' zonder dat er nog een getelde grootheid bij genoemd wordt. Kan men zeggen: in anjin tiga ekor is ekor gehypostaseerd tot classificator? Ja, m.i., wanneer er een klasse van woorden zou zijn die als regel niets dan classificatoren zijn. Is dit niet het geval, dan zou men door deze woorden in hun functie van classificator tot een afzonderlijke woordsoortkategorie te verzamelen, hen tweemaal indelen. Hetgeen onmogelijk is, omdat we ons ten doel stellen het lexikologische materiaal van een taal, indien mogelijk, in kategorieën in te delen. Voor het Maleis zegt men m.i. het beste dat ekor etc., die, niet als classificator gebezigd, substantiva aanduiden, in hun functie als classificator als substantieven in bijzonder gebruik dienen te worden beschouwd.

Genoemde substantiva kunnen zich dus in het algemeen door andere woorden attributief laten bepalen - bijzondere gevallen verdienen nauwkeurig onderzoek. Ze staan dan vóór hun attribuut: oran muda; rumah bĕsar; bĕgitu pula kabar² nĕgĕri kita ini dijual kĕnĕgĕri luar; adapun pĕrusahaan kantor sĕmacam itu; sětělah $D$. mĕndĕnar kata $K$. děmikian itu. Het woord dat een substantief attributief bepaalt en in constructies als deze laatste onmiddellijk op het substantief volgt noemen we, wanneer het niet valt onder de hierna te noemen kategorie $i t u$ etc., een adjectief. De woordvolgorde is hier het belangrijke syntaktische criterium. Semantisch beschouwd drukken de boven aangehaalde adjectieven een kwaliteit uit ${ }^{1}$ ). Dat in praedicatieve constructies de volgorde verschillend is (gila oran itu) mag ons niet beletten de attributieve verbinding, waaraan we ook verder belangrijke criteria kunnen ontlenen, ten grondslag te leggen, juist omdat ze distinctieve kenmerken aan de hand doet. Adj. kunnen in verschillende positie ook een werkwoord bepalen: těrban laju; ia sěgĕra měñambil...

Een aantal adjectieven is, voorzover mij bekend althans, geheel gereserveerd voor 'adjectivisch' gebruik. Ze treden niet op als 'head'woord. Een compositum of 'phrase' van het type sakit hati ,ergernis” is eventueel in zijn geheel 'head'. Moet de 'uitgedrukte' idee substantivisch onder woorden gebracht worden, dan moet men naar afleidingen, 'samenstelling' (masa tua ,ouderdom" naast tua „oud”)

1) De Groot spreekt van ,non-numerical objective accidence words" (p. 468). 
etc. grijpen. Zo heeft men mogelijkheid van transpositie, en doet bv. de affix-combinatie $k \breve{e}$-an dienst als transpositeur(murah $: k e ̆ m u r a h a n$ ). Meermalen mag echter de adjectivische functie overheersen zonder dat een substantivische uitgesloten of zelfs maar zeldzaam is, iets wat uiteraard woord voor woord vastgesteld moet worden. In het laatste geval kan men, als men wil, van hypostase spreken: dĕnan en -nya bepalen de substantivische functie van mudah). Ook andersom kan een substantief met hypostase adjectivisch fungeren: wanneer men bv. de uitdrukking rumah raksasa itu vindt zo dat niet een ,huis van reuzen" maar een "reusachtig huis" bedoeld is. Vergelijk ook gevallen als baginda itu ... sañat "adil lagi pĕmurah ${ }^{\mathbf{1}}$ ) (Indera Bangsawan 3) naast děnan 'adil dan murah (S.M. 74). Men vergelijke gevallen als fr. Jean est très artiste (als Jean est très habile), waarin het praedicatief gebezigde subst. tot adj. is gehypostaseerd (très artiste en niet grand artiste). Door veelvuldige hypostasering kan een woord in de loop der ontwikkeling tot een andere woordklasse overgaan. Dit mag op het eerste gezicht vreemd lijken, het is het geenszins, ook niet in IdG. talen, waar oorspronkelijk subst. en adj. niet zo duidelijk van elkaar afgescheiden waren als de geijkte schoolleer pleegt te suggereren, en waar bovendien in de loop der ontwikkeling telkens overgangen plaats hebben. Bijzonder illustratief is hier het Engels, waar praedicatief, attributief en appositioneel gebruik (woordpositie) de overgang van subst. in adj. begunstigt. Daarbij treden lang niet steeds alle kenmerken van een volledig adjectief op. Een toegevoegd adverbium maakt echter het adjectivische karakter van master duidelijk in he is fully master of the subject ${ }^{2}$ ). In het Nieuw-Engels zijn bv. commonplace ( $I$ am so commonplace that I should not be understood by you), middle-class (the middle-class mind) e.a. zo gewoon in attributieve positie, dat ze soms, als in het geciteerde voorbeeld van commonplace, volledig adj. zijn - men vergelijke ook gevallen als there was a purely family gathering ${ }^{3}$ ). Een woord als cheap heeft al lang zijn oorspronkelijk karakter van subst. (Oud-Eng. cēēp, n. „prijs, "bargain"”, in het M.-Eng. biggen gōd chēp "to buy at a good price", i.e. "to buy something cheap") verloren. In het Latijn bestaan welbekende

1) Zie ook beneden, p. 300 .

2) Zie H. Poutsma, A Grammar of Late Modern English, II The Parts of Speech, Groningen 1914, p. 25.

3) Zie M. Deutschbein, System der neuenglischen Syntax, Cöthen 1917, p. 211 . 
voorbeelden als homo frugi est ,de mens strekt tot nut" > „de mens is spaarzaam en degelijk".

Men zal nu op de z.g. grondwoordelijke werkwoorden van het Maleis willen wijzen: pĕrgi, naik, makan ${ }^{\mathbf{1}}$ ), main en zich afvragen of deze niet geheel op een lijn staan met muda, mudah etc. Deze zg. grondwoordelijke werkwoorden zijn weliswaar een vrij beperkte groep, maar ze worden over het algemeen veel gebruikt. Sommige als makan, minum zijn transitief en hebben daarin een kenmerk dat hen van muda, mudah onderscheidt: van minum kan een object afhangen dat in de zin terstond volgt: si Ali minum tèh, van muda niet. Andere kunnen onmiddellijk na zich een richtingsaanduidend woordje als $k \breve{e}$ „naar”, di ,te” krijgen: ěnkau datà் di Surabaya, tuan pĕrgi kĕkota; ook dit in tegenstelling met muda etc. De grondw. wwd. kunnen voorts als uitdrukking van een gebod fungeren: perrgi! En zo als head optreden. In andere IN. talen liggen hier eveneens merkwaardige punten van verschil. In het Toba Bataks kenmerkt het adjectief zich, in tegenstelling tot het grondw. wwd., door een variabele toon en door de constructie met na ${ }^{2}$ ): bian na bólon, ,een grote hond”; bolón do biain on ,,deze hond is groot". Daarbij komt, dat èn het type minum èn het intransitieve type tegenover muda, sakit etc., die we adjectieven noemden, in gewone taal de mogelijkheid missen verbindingen aan te gaan met woorden en affixen, die een graad aanduiden. Men kan zeggen: daripada sĕgala rumah itulah yan tĕrběsar; oran் itu ialah yan் těrlěbih sakit; sěpohon randu amat tingi; ia těrlalu gagah běrani; těrlalu sěkali permai rupanya; si $A$ kaya daripada si $B$; yan் sěkayakayanya etc. etc. Men kan echter in deze zinnen en woordgroepen de woorden die we adjectief genoemd hebben niet vervangen door 'grondwoordelijke' werkwoorden (tenzij natuurlijk in bijzondere gevallen, wanneer de spreker een bijzonder effect wil bereiken etc., in incidentele hypostasering). De adj. laten verbindingen en afleidingen toe die aequivalent zijn met de trappen van vergelijking etc. der IdG. talen, de werkwoorden niet. De laatsten laten zich, evenals $m \breve{e}$ - vormen enz., verbinden met een object of met woordjes uit de groep $k \breve{e}$, $d i$ etc. Een belangrijk criterium der werkwoorden is óok, dat zij de zg. hulppraedicaatswoorden, waarover beneden nog sprake zal zijn (beter gezegd wijzers als boleh etc.), bij zich kunnen nemen; de adj. doen dit in de regel niet. Mij dunkt, reden genoeg om beide groepen te onder-

\footnotetext{
1) Taalgeschiedenis blijve hier buiten beschouwing.

2) Vergelijk J. H. Meerwaldt, Handleiding tot de beoefening der Bataksche taal, 1904, p. 70 vlg.
} 
scheiden. Nu kan men wel opmerken, dat de mogelijkheid van verbinding met graadaanduidende woorden bij kaya etc. en de afwezigheid daarvan bij de werkwoorden voortvloeit uit de aard van de betekenissen door de vertegenwoordigers van beide groepen uitgedrukt: sommige laten gradatie toe, andere niet. Evenals men opmerken kan, dat er verband is tussen de betekenis van Eng. thin en zijn adjectivische woordsoort enerzijds en tussen blood en zijn substantivische woordsoort anderzijds. De syntaktische verschillen bestaan echter, al zijn ze in de ene taal kleiner dan in de andere. De opmerking herinnert ons er echter aan, dat de factor betekenis zich telkens en telkens weer manifesteert ${ }^{\mathbf{1}}$ ).

Dat menig woord zowel substantivisch als adjectivisch kan optreden is niets bijzonders: ook andere talen - men denke aan het Engels: good, cold, blue etc. etc. - kennen dat verschijnsel: het Maleis heeft welbekende gevallen als pěrigi yan் dalam naast tiada těrduga dalamnya etc. Bij de afgeleide woorden doet zich echter de vraag voor hoe hier de woordvormingskategorieën zich tot die der woordklassen verhouden. Laten ze zich - we bespraken de vraag reeds - er onder subsumeren, zodat men bv. van bepaalde klassen van derivata kan zeggen, dat ze altijd substantief zijn of doorkruisen beide classificaties elkaar?

Bedenken we eerst, dat ook in de IdG. talen waar de formele criteria zich vaak zo sterk opdringen, zich gevallen voordoen waarin een bepaalde woordvormingskategorie zich niet volledig tot een bepaalde woordsoort laat rekenen. Bij de nomina agentis is van ouds substantivische zowel als adjectivische functie gewoon. Terecht zegt Wackernagel ${ }^{2}$ ), dat we hier ,,vielleicht nicht einmal von Verschiebung (vom Substantiv zum Adjektiv) sprechen dürfen, weil da von jeher beide Funktionen vorkamen". De zg. nomina agentis treden in Grieks en Latijn deels substantivisch, deels adjectivisch op. „Ein Wort wie

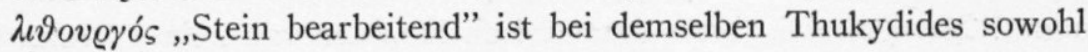

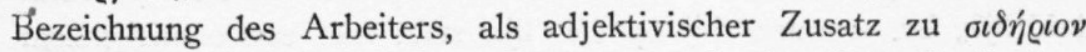
(,ijzeren werktuig”)". Of het Gr. po@ós primair „drager” of „,dragend" betekent valt niet te zeggen. In het Sanskrit heeft men tal van voorbeelden: kathaka- betekent zowel ,verteller" als ,vertellend”, in adjectivische functie kan bij deze woorden op $-a k a$ - verbale rectie optreden, dwz. ze kunnen een afhankelijke objectsaccusatief bij zich

1) Men merke op welk een plaats de betekenis in het aangehaalde artikel van De Groot inneemt.

2) J. Wackernagel, Vorlesungen über Syntax, II, Basel 1928, p. 53. 
hebben; denk voorts aan gäyana- „zanger", maar cetana- „waarnemend, bewust”, enz. In het Latijn betekent tiro „recruut”, maar in tirones milites en in exercitus tiro is het adjectief. Zeer duidelijk en door Wackernagel en anderen met vele voorbeelden geillustreerd laat zich dit verschijnsel waarnemen bij de nomina agentis bij uitstek, de klasse in het Latijn gevormd met -tor- Victor is niet alleen „overwinnaar", maar men vindt ook exercitus victor, en ook equus bellator „strijdros”, ook bij niet-bezielde en niet-levende zaken als subst.: altores suci „,voedende sappen”. Sommige geleerden hechten er aan hier van quasi-adjectiva te spreken die door 'Gliederungsverschiebung' uit oorspronkelijke apposities ontstaan zijn ${ }^{1}$ ), een feit is, dat Cicero het woord corruptrix na een adverbium volkomen als adjectief bezigt: in tam corruptrice provincia. In het latere Latijn neemt het adjectivische gebruik van deze -tor-woorden toe, speciaal in populaire (volkstümliche) teksten en in het Portug. bv. vormt de kategorie (als -ador: abrigador „beschermend”) volkomen adjectivische woorden.

We halen dit alles op, omdat, gelijk bekend, de Maleise p̌e-vorm, die ,agens-aanduider bij uitnemendheid” is, eveneens, zoals Emeis ${ }^{2}$ ) het uitdrukt, ,als bepaling van een ander zelfstandig naamwoord" optreedt : in siapa pěnarañ kitab ini is het zuiver subst., in obat pĕnidur „slaapmiddel”, kapal pěnainkut „transportschip” etc. vinden we pendanten van equus bellator. In pisau pěmoton roti heeft de pěe-vorm een object bij zich ${ }^{3}$ ). Een vergelijking met verwante talen zou op dit punt interessante bijzonderheden aan het licht brengen - het Bataks vertoont bv. reeds merkwaardige verschillen met het Maleis -, doch een historisch-vergelijkend onderzoek zou ons hier te ver voeren en bovendien overbodig zijn: in het huidige Maleis liggen de feiten zoals gezegd. Als zuiver adjectief moet een p̌r-vorm in een woordgroep van het type obat pěnidur worden beschouwd zodra het de andere characteristica van een adj. (toevoeging van amat, těrlěbih etc.) aanneemt. Menigmaal is het substantivisch karakter van zo'n pěe-vorm duidelijk, bv. wanneer hij op één lijn staat met een onmiskenbaar substantief : daripada gaji ... ia měnyĕrahkan sětěnah kĕtañan $S$. pĕnutup bĕlanja tumpanan, uà sěkolah dan pěncuci pakaian adiknya.

Ook van diachronisch gezichtspunt laat zich een en ander opmerken.

1) J. B. Hofmann, in Stolz-Schmalz, Lateinische Grammatik ${ }^{5}$, München 1928 , p. 458. Aardig is, dat J. van Wageningen, Latijnsch Woordenboek ${ }^{2} 1914$, onder bellator spreekt van adject., onder victor van appositie.

2) M. G. Emeis, Inleiding tot de Bahasa Indonésia², 1948, p. 142.

3) Zie ook gevallen als aangehaald door Emeis, o.c., p. 143. 
Zoals bekend heeft het Maleis geen adjectivische afleidingen van stofnamen (trouwens, heeft het Nederlands ze van ijs, melk?): cincin ěmas ,gouden ring”, pagar batu etc. In een uitdrukking als bĕrsuji ěmas diragam ,,bestikt met geborduurd goud” wordt ěmas door diragam bepaald: kenmerk van een substantief. In modern Maleis fungeert zo'n stofaanduidend woord, ongetwijfeld onder Nederlandse

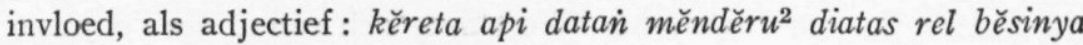
(vgl. thans rumah běsarnya tegenover klassiek rumahnya yan் běsar).

Komen we thans tot de bĕr-vormen. Gelijk bekend, komen deze in verschillende functie voor. Enige voorbeelden: maka sěkalianpun tĕrkĕcut... dan takut mělihat gajahnya itu, disanikanya bukit běrjalan (attribuut; Sang Boma, p. 136 V.L.) ${ }^{1}$ ); sětělah dilihat oleh sěoran் hulubalañ raksasa yaì amat gagah běrani dĕnan saktinya bĕrnama S.P.G. ... (attributieve of appositionele bepaling); maka bagindapun bĕraìkatlah dari sana (praedicaatswoord; Sej. Mel.); ia bĕranak sěoran் pěrěmpuan (idem) ${ }^{2}$ ); maka bĕrpaliñlah ia měṅhadap kĕpada raja $I$. (idem); maka oran் itupun pěrgilah běrtanya pada orań pilau itu (,gaan (om te) vragen”) ${ }^{3}$ ). Een bĕr-vorm kan een gebod uitdrukken: bĕrjalan! Daarmee is nog niet alles gezegd. Vele bĕr-vormen zijn intransitief : bĕrlěnkap, bĕrĕnain etc.; vaak evenwel volgt terstond een woordje van de groep kĕ, di etc.; maka lěbu dulipun berrbanikitlah kěudara. Frequent zijn bĕr-vormen in reciproque zin ${ }^{4}$ ) gevolgd door děnan: běrsambutan děnan. Er is echter ook menig voorbeeld van $\mathrm{zg}$. transitieve bĕr-vormen met onbepaald object, het vaak aangehaalde type ia berrjual kuda, ,hij verkoopt paarden” (in het algemeen, als beroep), en ook een bepaald object laat zich vinden: L. itupun mandi pada kolam běrsuci tubuhnya $(\text { H.T. })^{5}$ ). Onder de indruk van de omstandigheid, dat op ons een bĕr-vorm soms een verbale functie lijkt te hebben (lalu bĕrpĕraìlah kĕdua pihak ra $a^{\circ} y a t$ ), dan weer die van een kwalificerend adjectief: baju saya bĕrdarah; bukit berrjalan, hebben verscheiden auteurs zich, gelijk bekend, uit de

1) Bijzondere gevallen, waaraan men in de leer van de 'phrases' ('woordgroepen' als men deze term als vertaling voor het Engelse begrip gebruiken wil) en 'composita' alle aandacht besteden moet, laten we hier achterwege: gĕndĕran் of gĕndan் bĕrankat naast $g$. kĕmbali, $g$. pĕran், $g$. pĕrhĕntian etc.

2) Voorts bĕr- 'voor een woordgroep': binatan itu bĕrkaki ěmpat.

3) Over deze constructietypen M. G. Emeis, Vorm en functie in klassiek en modern Maleisch, Diss. Utrecht 1945, p. 4 vlgg.

4) Uitvoerig bij R. Roolvink, De voorzetsels in klassiek en modern Maleis, Diss. Utrecht 1948, p. 52 vlgg.; 174 vlgg.

5) Voorts nog trans. bĕr-kan vormen: bĕrnantikan adinda tuan ini (HT. 135). 
moeilijkheid trachten te redden door van deelwoorden te spreken. Tegen het gebruik van deze term, die men ook bij auteurs van werken over andere IN. talen vindt, kan men m.i. bezwaar maken ${ }^{1}$ ): noch

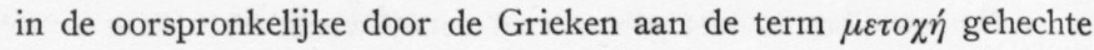
zin, noch in de technische zin der huidige Indogermanistiek zijn deze IN. vormen deelwoorden. Bovendien is bv. een Engels deelwoord al iets anders dan een Nederlands. Weet men zich van al deze onjuiste associaties los te maken, dan mag men mijnentwege de term om praktische redenen in het Maleis bezigen als verzamelnaam voor alle zg. niet-vervoegde verbale vormen ${ }^{2}$ ). Maar waarom dan niet die negatieve term? Wat betreft de verschillende indruk die bĕrdarah, vaak geïnterpreteerd als „zijn met bloed”, bĕrnama ,genaamd zijn, een naam hebben”, běrankat ,vertrekken" maken - hoeden we er ons voor zelf uit te maken wat in het Maleis een proces is (indachtig aan rood zijn = lat. rubēre) en wat niet. Zodra een attributieve běrvorm ook de andere kenmerken van een Maleis adjectief heeft (dus zodra bv. těrlalu, lěbih etc. erbij optreden), kunnen we gerust van een adjectief spreken. Vgl. ook wendingen als S.B. 142 D. mĕlihat muka S.P. amat bĕrsěri ${ }^{2}$; H.T. 216 sěpěrti oran் běrarak lakunya. Een praedicatieve, een die het praedicaatswoord is en kenmerken van een verbum heeft, kan men een verbum noemen. Of wel men kan zeggen, dat de b̌r -vorm in dat geval verbaal fungeert. Kan syntaktische vervangbaarheid hier een vingerwijzing geven?: maka R.S.P. pun bĕrděbar ${ }^{2}$ hatinya (Sang Boma); sĕrta bĕrnyala ${ }^{2}$ běrkilat ${ }^{2}$ rupanya beantwoorden in constructie geheel aan maka iapun těrlalu sukacita hatinya, waar sukacita adjectief is; maar daarnaast bělum sampai bilañannya (S.B. 141).

In een zin als ... Amerika, nĕgěri yà் běsar dan luas itu, něgěri yan் bĕrgunun tingi ${ }^{2}$, bĕrlĕmbah dalam ${ }^{2} \ldots\left(\right.$ (Hk. $\left.32^{3}\right)$ ) staan de běrvormen syntaktisch geheel op één lijn met de adjectieven běsar en luas. In andere gevallen wijzen o.a. kĕ, dari etc. op verbale functie: ... si musafir yan் bĕrpěsiar dari suatu bahagian nĕgĕri kĕbahagian yaì lain (Hk. 33). Evenzo een object ${ }^{4}$ ): běroleh kĕběsaran; bělajar elmu bumi (natuurlijk ook bĕrhĕntikan lělah kuda). Feitelijk afwezigheid van $k \breve{e}$ etc. mag ons er niet van weerhouden van verbale functie

1) Zie mijn uiteenzetting in Een onbevredigend behandeld punt in de Maleise grammatika, Bijdr. 97 , p. 522 vlgg.

2) Zo bv. C. Spat, Maleische taal 4 , 1920, § 171 vlgg.

3) Hk. = C. Hooykaas, Modern Maleisch zakelijk proza.

4) Ondanks Gerth van Wijk, Spraakleer ${ }^{3}$, § 196. 
te spreken. Verkeert men in een bepaald geval in het onzekere, dan late men de vraag naar de woordsoort onbeantwoord ${ }^{1}$ ), evenals m.i. bij dubia van grondwoordelijke en andere formele woordklassen aanbelevenswaardig is. Substantivisch fungeert een bĕr-vorm in didalam berrkata ${ }^{2}$ itu (Hang Toeah V.L. 215). Op wendingen als $d u d u k$ berrsama $^{2}$,bijeen zitten”; běrsama ${ }^{2}$ bĕrjalan komen we beneden terug.

De aandacht verdienen ook de těr -vormen. Kunnen deze diachronisch m.i. bevredigend uit een grondfunctie van těr- verklaard wor$\operatorname{den}^{2}$ ), van synchronisch gezichtspunt lijkt het mij onmogelijk ze steeds met feilloze zekerheid naar woordsoort te definiëren. Vast staat in de eerste plaats, dat er těr-vormen zijn, die gewoonlijk onder de $\mathrm{zg}$. adverbia thuis behoren. Verder zijn er veel gevallen van 'verbale' functie. Bv. S.B. 102 jika dapat buna, niscaya taian tĕrguris oleh duri itu, waar de agensaanduider oleh optreedt (vgl. 114 kalau $^{2}$ ia kĕna tĕrbunuh oleh kami ini); men bedenke hierbij, dat een eventief woord of eventieve vorm (een die uitdrukt dat het subject of een substantie iets overkomt, door iets getroffen is, met iets behept is etc.) zeer wel van een aanduiding van een aanleiding of oorzaak (door wiens directe of indirecte toedoen dat zo is) vergezeld kan zijn, zonder dat men deze een agens en de vorm passief kan noemen ${ }^{3}$ ). Voorts (Pel. Djen., V.L.) dapat těrtolak bala hamba daripada harimau itu; (Alisjahbana, Laj. Terk.) hari Mïngu ... akan tĕrlañsun rapat 'umumnya, waar de wijzers dapat en $a k a n^{4}$ ) optreden. In andere gevallen verschijnt een $t \breve{r} r$-vorm vaak in adjectivische functie: iedere gedachte aan een agens is afwezig in (Sedj. Mel.) sĕpěrti perak yain tĕrupam $\left.{ }^{5}\right)$; (H.T.) ... datan bĕrlari ${ }^{2}$ děnan kĕris tĕrhunus; zeer duidelijk S.B. 106 dayañ $^{2}$ yan் těrtua daripada ...; vgl. een di-vorm in adject. functie als běsi dituà ,gegoten ijzer”. Gesubstantiveerde gevallen, althans subst. functie, vinden we in uitdrukkingen als dĕnan těrgopoh ${ }^{2}$ en een 'kras' geval ${ }^{6}$ ) als lampu gantun ditěñah ${ }^{2}$... sama běrsih dan tĕrpěliharanya děnan sěkalian baraì lain $^{2}$, beide uit modern Maleis van A. Moeis. Meermalen kan men deze vorm zien optreden

1) In het bovenstaande zijn niet alle syntaktische posities van de bĕr-vormen besproken.

2) Zie mijn opstel: Een onbevredigend behandeld punt in de Maleise grammatica, Bijdragen, 97 , p. 515 vlg.

3) Zie mijn boek The Sanskrit Passive (Brill, Leiden) voor nadere bijzonderheden. Vgl. mal. pěnuh sěsaklah padañ oleh manusia.

4) Waarover beneden, p. 313 vlgg.

5) Over yan beneden, p. 310 .

$\left.{ }^{6}\right) \mathrm{Zie}$ Emeis, Vorm en functie, p. 115.

D1. 105. 
bij een verbale vorm: (Si Miskin) iapun těrsĕdu ${ }^{2}$ měnainis; S.B. 95 ia tĕrkĕcut bainun; 103 D.J. pun těrkĕcut mĕndĕnar suara, of bij een praedicatief adj.: S.B. 106 dayañ ${ }^{2}$ itupun ramailah těrtawa ${ }^{2}$. Dat wij geneigd zijn te interpreteren „weende snikkend”, ,stond verschrikt op”, ,schrok toen ze hoorde”, ,lachten vrolijk”, mag natuurlijk geen maatstaf zijn. Andere wendingen kunnen soms een vingerwijzing geven: S.B. 105 R.S.P. pun tiada těrtahani lagi hatinya mĕlihat kĕlakuan... (mělihat 'appositioneel'): cf. boven S.B. 103; héran tĕrcĕnà்: tweelingformule. Maar, al blijft de mogelijkheid van oorspronkelijk asyndeton van twee op één lijn staande praedicaatswoorden open - diachronische kwestie, die we hier kunnen laten rusten -, men zal ia těrkěcut baíun niet als een dergelijk asyndeton mogen verklaren op grond van gevallen als B.S. 104 D.D. tërkĕcut, lalu ia bĕrpalin. Het woord těrkĕcut kan ook ,plotseling” betekenen, en staat op de plaats waar bepaalde 'bijwoorden' plegen te staan: raja $^{2}$ itu bĕlum kĕmbali: het maakt dus de indruk 'adverbiaal' te fungeren. Anders staat het met S.B. 186 ... lalu jatuh těrjĕrumus.

In dit verband zou men bepaalde formaties in verwante talen eveneens aan een onderzoek kunnen onderwerpen: de door Van der Tuuk ${ }^{\mathbf{1}}$ ) ten onrechte 'nominale werkwoorden' genoemde tob. -on vormen bv. (miseon ,een lelijke snor hebben, er bar uitzien”; panogonogon ,korzelig van aard (zijn)"), de daarmee corresponderende Javaanse vormen etc.

In het klassiek Maleis is jadi praktisch het enige woord, dat aan onze koppelwerkwoorden herinnert: děnan pĕrniagaan itu ia jadi(měnjadi) kaya. In naik raja etc. heeft naik een bijzonder gebruik. Trouwens ook jadi heeft als "geboren worden; ontstaan" een andere functie, waaruit die als 'koppelwerkwoord' begrepen kan worden.

Het zou voor de leer der woordsoorten in het Maleis en andere IN. talen stellig zijn nut hebben de transpositiemogelijkheden na te gaan. Niets is gewoner dan dat een grondwoord, dat we vaak in adjectivische functie aantreffen of dat zelfs usueel adjectief is, bv. door achtervoeging van het pronominale suffix in possessieve betekenis substantivische functie aanneemt: kain itu buruk: buruknya kain itu... Men zou een onderzoek kunnen instellen naar de frequentie waarin deze mogelijkheid gerealiseerd wordt - bij ieder woord afzonderlijk uiteraard - en vaststellen welke grondwoorden in de praktijk het poss. pron. suffix nooit of zo goed als nooit aannemen

1) Van der Tuuk, Tobasche Spraakkunst, § 134. 
en verder nagaan of zou blijken, dat de grondwoorden waaraan we om andere redenen met de minste aarzeling een verbaal karakter kunnen toekennen als geheel minder vaak -nya etc. aannemen dan de adjectivische (bedoeld zijn dus gevallen als datainna itu tiada dikětahui oleh D.J.; terrlalu banyak matinya, S.B. 103 en 114).

Ook andere transpositiemogelijkheden verdienen de aandacht. De adjectivische grondwoorden, bv., laten zich transponeren in substantiva met $k \breve{e}--a n: k \breve{e}--a n$ bij uitnemendheid de formatie om de eigenschap in de gedaante van een substantief uit te drukken ${ }^{1}$ ): kain itu buruk „die doek is versleten”: kĕburukan kain itu ,het versleten-zijn, de haveloosheid van de kain". Zo vindt men kĕpandaian „bedrevenheid"; kěmurahan ,,mildheid” ; kětingian ,verhevenheid” en andere. Maar men vindt ook kĕdatanan ,de komst, het komen” bij het verbaal fungerende datan; kĕpindahan,,verhuizing" bij het eveneens verbaal fungerende pindah. Ofschoon deze transpositiemogelijkheid dus geen criterium vormt dat de boven besproken criteria voor het beantwoorden van de vraag: wanneer verbaal, wanneer adjectivisch? dekt, zou een volledig overzicht van wat in de praktijk in verschillende fasen der taal voorkomt interessant zijn.

Ook de pĕ-woorden zijn uit een oogpunt van transpositie van interesse en wel voor de vraag naar de grens tussen enerzijds substantivisch, anderzijds adjectivisch en verbaal fungerende grondwoorden. p̌e-, waarover boven al sprake was, vormt, leren de grammatika's, nomina agentis en nomina instrumenti naast mě-vormen (pĕnirim

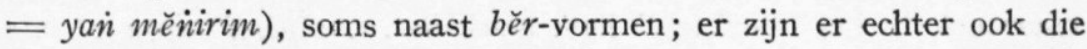
op adjectiva gebouwd zijn: si pěndinin ,de koukleum”. Ook pĕnyakit „de ziekte” bij sakit. Derivaten van substantiva zijn echter zeldzaam: mula ${ }^{2}$ oran் asin itu datà sěbagai pělaut ${ }^{2}$ ). De historisch-vergelijkende grammatika moet, zo mogelijk, trachten hier licht te verschaffen.

Komen we thans tot die groepen van woorden die de grammatika's plegen samen te vatten onder de term pronomina, dan vinden we bij de zg. personalia weer eens een formeel kenmerk. Naast ia data $\dot{n}$ immers, waarin ia zelfstandig is en subject, staat bapa-nya, naast $a k u$ :

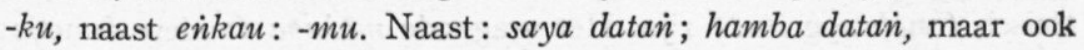
bapa saya; hati patik. Er bestaat bovendien nog een gepraefigeerde reeks met subjectsfunctie: kau-katakan naast kami katakan, patik katakan. Bij ia (3e pers.) bestaat zelfs een objectsvorm (dia), die

1) Emeis, Inleiding (zie boven) ${ }^{2}$, p. 147.

2) Geciteerd door Emeis, Inl.2, p. 144. 
intussen ook veelvuldig andere functies heeft (relief etc.). Deze pronomina kennen dus subjectieve functie in nominale zinnen en in verbale zinnen met niet-vervoegde werkwoorden; daarnaast hebben ze possessieve functie, waarbij ten dele andere vormen optreden; tenslotte vindt men ze als subject in andere dan de genoemde verbale zinnen met ten dele bijzondere vormen; met name gaan ze onscheidbare verbindingen aan met de 'korte stam-reeks' van de transitieve werkwoorden: ku-lihat. Ze kunnen als patiens (object, complément direct) optreden en ook na praeposities. Ze kunnen niet attributief gebezigd worden en laten zich evenmin met bepaalde telwoorden verbinden. Ook laten ze geen verdubbeling of aanhechting van affixen toe. Evenmin bepaling door adj., subst., adv. etc.

De woorden ini en itu, de zg. aanwijzende voornaamwoorden, onderscheiden zich in het Maleis niet alleen door eigen betekenis en functie, maar ook door hun plaats in de zin: heeft een substantief een attributief adjectief en $i n i$ of $i t u$ bij zich, dan staan laatstgenoemde op de laatste plaats van deze groep van drie: rumah běsar itu; ook: bazvalah patik sěkalian ini bĕrsama ${ }^{2}$. Deze rangorde rumah běsar itu correspondeert met die in Nederlands (dat (het) grote huis), Frans, Engels etc. Een woord als tadi „zoeven, onlangs” sluit zich daarbij vaak aan: malam tadi, oran் berrjalan tadi. Dat ini en itu ook een andere positie in de zin (in andere wendingen) kunnen innemen, kan onbesproken blijven: de mogelijkheid van genoemde positie is kenmerkend. Opmerking verdient, dat itu niet alleen in het 'Zeigfeld', maar ook in het 'Denkfeld' ligt: anak itu ... sĕpěrti suatu cěrmin „(de) kinderen zijn als een spiegel”. - Het woord diri ,zelf” is een substantief : diriku etc.

De groep der zg. vragende voornaamwoorden verdient afzonderlijke aandacht. Siapa, wie"? is een substantivisch vragend voornaamwoord: siapakah cakap měnjadi nachoda?; rumah siapa itu? Mana, dat vraagt naar afkomst, herkomst (ook naar wie of wat uit een bepaalde groep) etc., is adjectivisch: kěpada jalan mana baik kita ikut? rumah mana? „welk huis?” $A p a$ kan substantivisch (apa dikandanmu?) of adjectivisch (anak apa itu?) zijn. Het vragende měnapa (andere functie: tiada měnapa „het maakt niets uit”) is een werkwoordsvorm die een andere uitdrukking van een proces bepaalt : mĕnapa polisi tidak měnankap oran் pĕnipu itu? Bĕrapa ,hoeveel” staat vaak op één lijn met banyak, en is formeel een berr-vorm. Bĕtapa „hoe, hoedanig” (ook wel $=$ sĕperrti) kan adjectivisch optreden: bĕtapa pěrinya ? Met $a p a$, dat ook voor het bepaalde woord kan staan (oorspronkelijk onge- 
twijfeld emfatische positie) : apa macam? ,wat voor soort?...”, zijn verschillende andere uitdrukkingen gevormd, zoals apabila? $(<a p a$ + bila „tijd”) ,wanneer ?” Men kan dit een vragende tijdsbepaling noemen ${ }^{1}$ ). Alle vragende woorden hebben uitgesproken voorkeur voor gereleveerde plaats in de zin, de attributieve uitgezonderd.

Men herinnert zich de theorie der ranks ,rangen, graden” van Jespersen ${ }^{2}$ ): "In any composite denomination of a thing or person we always find that there is one word of supreme importance (wil men: een kern) to which the others are joined as subordinates. This chief word is defined (qualified, modified) bij another word, which in its turn may be defined (qualified, modified) by a third word, etc. We are thus led to establish different 'ranks' of words according to their mutual relations as defined or defining". In erg koud water is water primair, koud, dat water bepaalt, secundair, erg, dat koud bepaalt tertiair. Eventuele nadere bepalingen van erg zou men quartair kunnen noemen, maar ze gedragen zich geheel als erg (vreselijk erg koud) : ze kennen evenmin als erg flexie, zijn met tertiaire woorden onderling verwisselbaar. Daarom noeme men ook deze tertiair. Een groep als de genoemde noemt Jespersen een junction, een secundair woord in een junction adjunct, een tertiair subjunct. Er kunnen twee of meer gecoördineerde adjuncten bij eenzelfde primair woord optreden: much (II) good (II) white (II) wine (I). Zo: rumah (I) běsar (II) ini (II). Jespersens terminologie kan voor ons enig nut hebben. In het Maleis bestaan n.l. ook bepalende woorden die vóór het bepaalde woord plegen te staan. In perrañ yan் amat b̌sar is $p$. primair, $b$. secundair, $a$. tertiair, amat is subjunct, en het staat op zijn gewone plaats, vóór het adjuncte. Aan dit amat kan zelfs tĕrlalu voorafgaan: gunun் yan் těrlalu amat tingi sĕkali, maar beide zijn, voorzover mij bekend, niet van plaats verwisselbaar. Amat kan ook een $m \check{e}$-vorm bepalen: Tuhan yan் amat mĕlihat „God, de Alziende” (Abdoellah). Zijn plaats en zijn functie, de aanduiding van een aanwezigheid in hoge graad van het begrip uitgedrukt door het volgende, bepaalde, woord plaatsen amat in een tot dusver onbesproken klasse. Klasse: woordsoort of grammatikale (syntaktische) klasse? Naast amat běsar ,zeer groot” vindt men ook běsar amat ,al te groot”, een wending, die op het eerste gezicht de indruk maakt te zijn ontstaan door affectief-releverend gebruik van amat in een 't.o.v. de norm' ${ }^{3}$ )

1) Over tijdsbepalingen beneden, p. 315 .

2) Jespersen, The Philosophy of Grammar, ch. VII.

3) Zie J. Gonda, Stilistische studie over Atharvaveda I-VII, p. 13. 
ongewone positie. Men vindt ook banyak amat in de zin van ,zeer veel": v. Oph., M.L. 139 banyak amat raja ${ }^{2}$ datan் bĕrbicara minta dihukumkan. Adjectivisch is amat I.B. 31 tĕrlalu amat děrasnya ${ }^{2}$ ).

Voor het bepaalde woord staat ook tĕrlalu. In M.B. pun těrlalu marah, dat we met Jespersen een nexus kunnen noemen, waarin $M . B$. primair (kern) is, $m$. secundair (adnex) en $t$. tertiair (subnex), staat $t$. op zijn gewone plaats. Vgl. zinnen als S.B. 230 maka berrpĕrañlah $t$. ramai; hinga těrlalu banyak yan mati. Tĕrlalu en amat kunnen echter ook als secundair wooord optreden: S.B. 187 maka C.S. pun tĕrlalu marahnya; v. Oph. M.L. 205.

$\mathrm{Er}$ is m.i. geen bezwaar tegen bovengenoemde tertiaire woorden (těrlalu etc.) adverbia te noemen. Vergelijk daarbij dan ook sanat in S.B. 187 sakitnya yà் těrlalu (quartair) sañat (tertiair) dirasainya; 234 karĕna ia sañat dipatuk oleh ... (anders I.B. 4 . . bĕrmain kuda těrlalu amat pantas baran் lakunya děnan sañat pandainya; 14 bundapun těrlalu sanat maçgulnya); sĕgĕra in zinnen als: iapun sĕgĕra naik kĕatas W.: maka s. dipĕgaì oleh ...; maka S.M.H. pun s. mĕlompat...; R.S.P. pun s. mĕmĕgan pingan S.M.H.; sĕgĕralah ĕíkau bunuh raksasa itu. De plaats in de zin is echter bij deze adverbia geen betrouwbaar criterium, al hebben ze vaak uitgesproken voorkeur voor een bepaalde positie. Daar een uitvoerig onderzoek naar de plaats van deze woorden ten opzichte van de voornaamste elementen der zin nog ondernomen moet worden, moeten we ons beperken tot enkele voorbeelden, die voldoende illustreren, dat men het meeste houvast heeft aan de aanwezigheid van tertiaire functie: v. Oph., M.L. 201 bañatlah hamba datai்; 138 jika hĕndak bañat adinda undur...; bĕnar achter het bepaalde woord: 198 sěnan bĕnarlah hati hamba; 203 lalim bĕnar raja itu; Hooykaas M.M.Z.P., p. 21 surat ... tiada digěmari běnar oleh ...; ia tĕrus jua bĕrjalan. Zwaardere adverbia, affectief-intensieve verdubbelingen zoeken vaak de laatste plaats: S.B. 184 marilah ěṅkau bĕrpĕgan் dibělakan்ku ini tĕguh ${ }^{2} ; 228$ sĕgala ra $a^{\circ}$ at ... undurlah pĕrlahan ${ }^{2}$; ia bĕrjalan gopoh ${ }^{2}$ etc. Dit brengt ons op een vaak aanwezig formeel criterium: de verdubbeling 'vormt' meermalen 'adverbia': pagi ${ }^{2}$,vroeg in de ochtend”; diam $^{2}$,stilletjes”; sia $^{2}$,vergeefs" $\left.{ }^{1}\right)$; tingallah tuan baik $^{2}$. Er zijn meer formele kenmerken, dwz. eveneens bij een deel der adverbia: sě-nya of $s \breve{e}-{ }^{2} n y a$ :

1) Zie mijn opmerkingen in The Function of Word Duplication, aangeboden aan het tijdschrift Lingua. 
kĕsĕnsaraan sĕbaliknya kĕrap kali mĕmpěrbanyak kĕlahiran jiza;

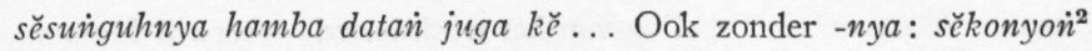
ia ada didalam pěperranan. Doch deze formaties zijn in wezen afleidingen van grondwoorden, die men, wat hun functie en plaats in het woordsoortensysteem ook moge zijn, toch niet of niet in de eerste plaats adverbia kan noemen: balik daripada berrjalan is ,van de wandeling terugkeren”; mělainkan Allah juga yan் suñguh „er is niets reëel dan Allah". En woorden als tĕrus (bĕrjalan $t$.) en vele andere vindt men ook in andere woordsoortkategorie: in sěpuh tĕrus „,verguldsel”, těrus mata ,helderziend” als adjectief ; sĕgĕra in dĕnan

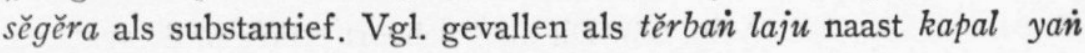
laju.

De vraag of deze en dergelijke woorden in 'adverbiaal' gebruik een eigen woordsoortkategorie vormen dient men m.i. ontkennend te beantwoorden: ze hebben als zodanig een bijzondere functie, nemen dan een andere plaats in en hebben in verband daarmee een andere betekenis. Een deel hunner heeft daarbij morfologische eigenaardigheden, maar woorden die in hun grondwoordelijke of, wil men, 'stam'vorm alleen adverbium zijn vindt men er nauwelijks bij, zelfs als men betoogt, dat amat een adverbium is, dat een enkele maal adjectivische functie heeft (hypostase). Ten aanzien van de adverbia van de typen sě-nya etc. nog dit: het grondwoord dat hun kern vormt komt bijna steeds als woord voor, in tegenstelling met de grondwoorden van vele werkwoorden etc.: bĕrěnain; měněndap; měnebok; těrtawa enz. enz. Beperkter in gebruik dan amat is sĕrba in sĕrba baru „splinternieuw” e.a. Historisch (etymologisch) is de plaats van sěrba te verklaren: het gaat terug op skt. sarva-, dat in de betekenis van ,in alle opzichten" vaak aan het begin van composita is aan te treffen en in het Maleis ook verbindingen met inheemse woorden heeft aangegaan. Zoals maha (dat tegenwoordig in zijn nieuwe verbindingen als maha guru opgang maakt en dat los wordt geschreven en om zijn afwijkende vorm en functie niet in het Maleise affixensysteem is geïncorporeerd) op skt. mahā in mahārāja teruggaat. Men kan amat met deze woorden in een groepje verenigen: èn hun plaats t.o.v. het kernwoord, èn hun functie en betekenis onderscheiden hen als een afzonderlijke lexikale kategorie.

In welbekende wendingen ${ }^{1}$ ) als duduk bĕrsama ${ }^{2}$, bĕrsama ${ }^{2}$ bĕrjalan

1) Zie ook Roolvink, o.c., p. 69 en 195 vlg 
(H.T.), die wij kunnen vertalen met „bijeenzitten”, „samenlopen”, fungeert běrsama ${ }^{2}$ als bepaling van het werkwoord - terwijl běrsama bv. in pĕmběrian bĕrsama ,een gezamenlijke gift” (Adi Negoro) als adjectief optreedt -, al zal deze berr-vorm oorspronkelijk in nauwere relatie tot het subject gestaan hebben. In dit verband valt aan frequente verbindingen te herinneren als o.jav. maluy ahurip tikain wanke (C.Ar.); maluy anidul manulwan ,,wederom keerde hij zuidwaarts, westwaarts” (Nāg. 55, 3); umeh těka ,bijna komen”, waar derhalve aan een Nederlands werkwoord met adverbiale uitdrukking twee werkwoordsvormen beantwoorden, en aan verbindingen als alawas ta sirâmětěn (Ādip. 68). Dit alles behoort echter in de syntaxis behandeld te worden.

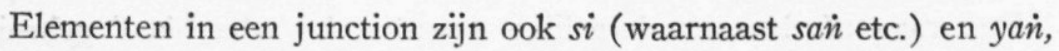
woordjes met onderscheidende, karakteriserende, releverende functie $^{1}$ ). Yan bepaalt vaak, si soms (si anak mati dibunuh) woordgroepen. $S i$ in si pěncuri is adjunct, evenals yan் in karĕna yan் kĕmatianku ini pada tañan L. (Niemann, B1. I, 75) ${ }^{2}$ ); těrlalu banyak yan mati (S.B. 230). In een zinsdeel van het type masa yai baik; hujan batu yan amat lěbat bepaalt yan் echter baik, resp. amat lěbat.

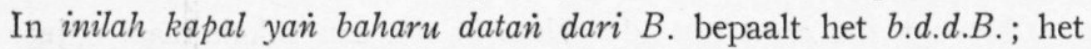
stelt deze woorden afzonderlijk, grijpt ze bijeen en bindt ze aan het voorafgaande. (Dit doet si niet). Het kan ook een $m \breve{e}$-vorm (werkwoord) substantiveren: S.B. 232 dan yan mě̀̃épalakan ratanya itu bĕrnama of een voorzetselgroep tot attribuut maken of adjectiveren:

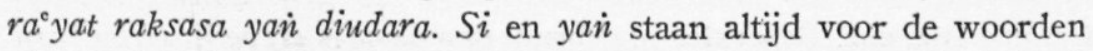
die ze bepalen. Ze vormen een woordklasse. - Het 'relatieve' těmpat (oran cina těmpat saya běli těmbakau) is een als appositie optredend substantief.

Ten aanzien van de telwoorden neemt de ouderwetse grammatika een even inconsequente houding in als ten aanzien van de voornaamwoorden. Terwijl ze bij niet tel- en voornaamwoorden tussen zelfstandige en bijvoegelijke scheidt vat ze deze groepen bij numeralia en pronomina in één woordsoort samen ${ }^{3}$ ). Evenals adjectieven zijn ze ,accidens van een substantie”, maar de zg. hoofdtelwoorden onderscheiden zich in het Maleis duidelijk van de woordsoort die we

1) Zie mijn opstel: Indonesische relativa, Bijdragen, 102, p. 501 vlgg.

$\left.{ }^{2}\right)$ Andere voorbeelden: Bijdragen, 102, p. 508, n. 2.

$\left.{ }^{3}\right)$ Andere kritiek bv. bij Jespersen, o.c., p. 85, die zich intussen eenzijdig door modern Indogermaanse talen laat leiden. 
adjectief genoemd hebben. Ze verbinden zich in alle Maleis met numeratieven zonder meer: kapal dua buah; ze staan vóór het woord dat ze bepalen, numeratief of substantief zonder numeratief: tiga raja itu; dalam suatu rumah ${ }^{\mathbf{1}}$ ). (In het Javaans is echter de gewone volgorde: won sugih tělu $i k u$ ). Deze eigenaardigheden worden gedeeld door tiap ${ }^{2}$,,ieder”: tiap ${ }^{2}$ hari; bĕrapa ,hoeveel”; pčlbagai ,allerlei” e.d. ${ }^{2}$ ). Dezelfde positie nemen in de met $k \breve{e}$ - gepraefigeerde zg. verzamelende telwoorden: kĕdua lěnannya ,zijn twee (beide) armen”. Deze groep is dus formeel gekenmerkt. Als rangtelwoord gebezigd, worden deze zelfde vormen echter, meestal door yan voorafgegaan, achter het kenwoord geplaatst: in rumah yain kĕdua is kĕdua adjunct en adjectief. Een woord als kira ${ }^{2}$ in de zin van ,ongeveer”, dat een telwoord bepaalt, is subjunct en bij de adverbia in te delen. In een groep sĕgala rumah ini zijn $s$, en $i$. beide adjunct; het eerste is onder de telwoorden te rangschikken, al neemt het het substantief zonder numeratief (classificerend woord) bij zich. Evenzo sěmuanya in sĕmuanya kapal itu (Abdoellah). En barañ in $b$. těmpat, ,de een of andere plaats”, $b$. ora $\dot{n} ; b$. siapa. In de wending kapal ini sĕmuanya is $s$. naar oorsprong een appositioneel gebruikt subst. : ,deze schepen, hun menigte (totaliteit)". Zonder hoofd- of onbepaald telwoord te zijn staan ook vóór het kernwoord de leden van het semantisch bijeenbehorende groepje waarvan běkas een voorbeeld is : běkas gubernur ,gewezen gouverneur". Historisch is deze opvallende positie te verklaren. En bakal měnantu ,toekomstige schoonzoon" naast bakal rumah „bouwmateriaal” stellende, kunnen wij geen nieuwe kategorie aannemen: bakal is een substantief.

Komen we thans tot de modale, temporale en aspectuale bepalingen van het proces.

Onder modus verstaat men, gelijk bekend, in een taal die formeel modale kategorieën onderscheidt, zoals het Sanskrit dat bv. doet (optatief bharet), die verbale kategorie, die de geestelijke houding van de spreker, van het sprekende subject ten aanzien van het proces uitdrukt; de wijze (lat. modus) waarop zijn geest het proces voorstelt. Een modus indicativus bezigend stelt de spreker van het Latijn een

1) Hierop zijn bepaalde, begrijpelijke, uitzonderingen, besproken door Emeis, Inleiding ${ }^{2}$, p. 18.

$\left.{ }^{2}\right) \mathrm{Zie}$ bv. A. A. Fokker, Beknopte Maleise Grammatica ${ }^{2}, 1946$, $\S 75$. De woorden lain en banyak sluiten zich in hun positie vóór het kernwoord bij semantische verwanten als sěgala, sĕtĕrah etc. aan, in die achter het woord bij de adjectieven. 
proces (gebeuren, feit etc.) als werkelijk (of als modaal indifferent) voor, zonder enige interpretatie. M.a.w. de modus indicativus drukt een neutrale, objectieve, indifferente houding van het subject uit. Andere modi stellen het proces voor met een interpretatie: de spreker hoopt dat het zal plaats hebben, beschouwt het als mogelijk, als wenselijk, als irreëel, etc. Een modus imperativus drukt een gebiedende houding van het subject uit, een modus vetativus een verbiedende. De oude Indogermaanse conjunctief drukt een wilsuiting uit (conj. voluntativus): (Vedisch) hantāham prthivīm imām ni dadhānīha veha $v \bar{a}$,welaan, ik wil de aarde hier of daar neerzetten"; Latijn (numquid vis?) : : abeas (,,is er nog iets van uw orders?”) :: ,dat je weggaat!”; of een proces dat men zich voorneemt (conj. hortativus of deliberativus) : (Latijn eamus ,laten we gaan”) ; of wel een proces dat men verwacht (conj. prospectivus) : (Vedisch: ,sluit een bondgenootschap met hem, dan zult ge overwinnen" - atha jayāsi). Niet alle talen hebben uiteraard dezelfde modi. Er zijn er bv. die een energicus bezitten, die een houding van stelligheid, van gedecideerdheid van de spreker t.a.v. het proces uitdrukken; men denke ook aan het Arabische w'allāhi la (energetisch partikel) 'adribannahu „bij Allah, ik zal hem zeker slaan". ${ }^{1}$ )

IN. talen plegen de modaliteit, dwz. dat wat IdG. talen uitdrukken door formeel onderscheiden modi, uit te drukken met behulp van afzonderlijke woorden, die men m.i. het beste modaliteitswijzers of, kortheidshalve, modale wijzers kan noemen. Dergelijke woorden zijn ook in IdG. talen niet onbekend, in vereniging met de modale vorm: zo drukt o.ind. $m \vec{a}$ mèt een bepaalde modus uit wat het Maleise janian alleen wil zeggen: een verbod. Men kan mal. jainan een modale wijzer noemen, evenals baran, dat een wens uitdrukt, een wijzer van de voluntatieve modaliteit is (zo ook moga $\left.a^{2}, m u d a h^{2} a n\right)$; pěrlu, wajib drukken de noodzaak uit, patut een gepast zijn, wenselijkheid of wat minder strikte noodzaak: patutlah sĕgala anak ${ }^{2}$ masuk sěkolah; sĕkaran் ini juga saya harus pulan; kamu mĕsti mĕnolon; saya pěrlu pěrgi kĕ ...; politik kĕdalam, yan் harus kita lakukan, harus ditujukan kěpada... De modale wijzers die een noodzakelijheid (in verschillende schakeringen) uitdrukken staan vóór het werkwoord of (en dan gaarne met lah voorzien) aan het begin. Bijzonderheden betreffende woordvolgorde (vgl. Kus, kau harus kisarkan pandaian

1) Bijzonderheden bv. bij C. Brockelmann, GrundriB der vergleichenden Grammatik der semitischen Sprachen (1913), II, § 80. 
hidupmu, Pantjaran Tjita, V.L. 60) verdienen nader onderzoek. Andere modale wijzers geven stelligheid aan: saya tĕntu dimarahi tuan; Halik těntu tělah mĕndapat ... (Pantj. Tj. 87); sěgala dunia ini dĕnan sěisinya niscaya akan binasa juga adanya (Alex., ed. v. L. 192) ; na een voorwaardelijke zin staat niscaya aan het begin: jika ĕṅkau tiada sĕgĕra turun ..., niscaya aku tĕrbainlah naik (S.B. 186). ${ }^{1}$ ) Daarmee zijn echter de mogelijkheden niet uitgeput: een woord als munkin dat thans veel als modale wijzer van mogelijkheid en ,kunnen (zijn)" optreedt (pĕrkara itu tidak muṅkin diumumkan), kan ook praedicaat zijn (munkkinkah nĕgĕri kita děnan sĕlamat mĕnyěbĕrañi masa kĕsukaran ini?) Zo ook patut in těrlalu patut lakunya. En door hun betekenis en functie als indicatoren van een houding van de spreker tegenover het proces, en door hun voorkeur voor bepaalde posities in de zin tekenen deze wijzers zich als een afzonderlijke kategorie af. Doch het aantal wijzers dat alleen wijzer is (janan) is zeer gering. Een aantal woorden van dezelfde functie is formeel gekenmerkt door het inhaerente achtervoegsel -nya, dat hier als transpositeur optreedt: afgezien van sěsunguhnya ,inderdaad” (dan $s$. dalam hal ini Sin Po boleh berrkata), dat tevens het praefix sĕheeft, andere woorden (rupanya ,blijkbaar, naar het schijnt”, agaknya „,waarschijnlijk, klaarblijkelijk”, hĕndaknya dat een verzachte wenselijkheid uitdrukt); deze delen zijn voorliefde voor de eerste plaats in de zin.

De genoemde wijzers zijn niet de enige in het Maleis. De zg. hulppraedicaatswoorden - als dapat : tětapi ada juga obat yan dapat kubĕrikan -, die m.i. meermalen het onderwerp zijn geweest van besprekingen, mank aan scheve voorstellingen ${ }^{2}$ ), zijn niet, zoals Gerth van $\mathrm{Wijk}^{3}$ ) en anderen willen, te beschouwen als werkwoorden (van „kunnen, vermogen, willen, van plan zijn”) of hulp(werk)woorden. Ze staan niet op één lijn met de woorden die tot de kategorie behoren, waaraan we hierboven de naam werkwoord niet hebben onthouden. En al kunnen ze als praedicaatswoord optreden, bij een werkwoord zijn ze wijzers van modaliteit. En ze scharen zich daarmee naast woorden als arěp, bisa e.a. in het Javaans en overeenkomstige woorden in verwante talen. Men kan deze zg. hulppraedicaatswoorden uit de zin schrappen en houdt dan toch correcte en volledige Maleise zinnen

1) Over niscaya nader beneden, p. 325 .

2) Men zie ook mijn opstel De zg. hulppraedicaatswoorden in Maleis en Javaans, Bijdragen, 102 , p. 95 vlgg.

3) D. Gerth van Wijk, Spraakleer der Maleische Taal ${ }^{3}$, § 175 (en § 218). 
over; alleen is dan het begrip ,willen, kunnen etc.” niet uitgedrukt: si A. (mau) mělawan akan daku ini; saya (hěndak) měnanyakan hal itu kĕpada tuan. Wat dit betreft staan ze geheel op één lijn met een woord als sěgěra in iapun (sĕgěra) naik. Evenals sĕgĕra zoekt bv. ook hĕndak in de affirmatieve zin de plaats onmiddellijk vóór het werkwoord: S.B. 9 iapun sĕgĕra datan் kĕpada ...; 7 kita hĕndak běrkata ${ }^{2}$ ěppada ... Gelijk boven al opgemerkt is, kan men een woord, dat door een wijzer van deze soort bepaald wordt verbaal noemen, een woord dat zich door graadaanduidende woorden laat bepalen adjectivisch.

Uit de Indo-Germaanse conjunctief van het type ,(sluit met hen een bondgenootschap), dan is te verwachten dat ge overwint" (vedisch ... atha jayāsi) ontwikkelde zich een temporeel gebruik van deze kategorie. Grieks $\check{\varepsilon} \delta \rho \mu a$ en andere vormen zijn oorspronkelijke conjunctief-vormen, die de functie van toekomst-uitdrukkende vorm op zich hebben genomen en dus futurum genoemd worden. Ook het Maleise hĕndak kan, gelijk bekend, optreden in temporele functie: saya hĕndak pĕrgi ǩ̆... Evenzo akan, waarbij 'modaal' ('finaal' ,om te") en 'temporeel' gebruik samengaan ${ }^{1}$ ) : beta akan mati esok hari (Sj. Bid.); běrlěńkap akan kěmbali. De normale plaats van deze woorden is terstond vóór het werkwoord ${ }^{2}$ ). Het is de taak van syntaktisch-stilistisch onderzoek de positie van andere woorden in bijzondere gevallen na te speuren. Woorden echter, die als regel een andere positie innemen, en bovendien duidelijk 'mots pleins' ${ }^{3}$ ) zijn, zal men echter moeten onderscheiden. Het woord kĕlak bv., in grammatika's ${ }^{4}$ ) in een adem genoemd met akan en hĕndak als ,uitdrukker van de toekomende tijd" enz., vindt men vaak achter het praedicaatswoord: apabila běrtěmu kělak děnan ... (Abd.); murkalah kĕlak baginda akan dia, of naast akan: tuanlah kĕlak akan mĕngantikan kĕrajaan ... (v. Oph. M.L., 136); tĕrain kĕlak tiada akan kalah (Pantjaran Tjita, 74). Dit woord, dat ,weldra, aanstonds, straks, later” betekent (Wilkinson geeft: ,perhaps; a word indicative of future possibility: dibělakàn kĕlak baharulah ěnkau tahu), wordt ook gebruikt in andere posities waar men akan e.a. niet vindt: pada masa patik tua kĕlak... (v. Oph., M.L., 43). Ik zou derhalve kĕlak

1) Uitvoeriger behandeld door Roolvink, o.c., p. 47 vlg. en 167 vlg.

2) Natuurlijk kan juga achter een woord als hĕndak komen: akupun hĕndak juga masuk... (V. Oph., M.L., p. 59).

3) Zie J. Vendryes, Le langage 1921, p. 98 vlg. Zie verder beneden, p. 319.

4) Gerth van Wijk, o.c., p. 150 vlg.; Spat, o.c., p. 208. 
e.a. niet opnemen onder de temporele en aspectuale wijzers bij het proces (proces-uitdrukkend woord) - waartoe ook tělah, těnah e.a. behoren: tuanhamba tělah lupalah akan...; hambamu tĕlah mĕlihat suatu nĕgěri -, maar onder de bepalingen van tijd, groep woorden die een onderzoek vanuit syntaktisch-stilistische gezichtspunten alleszins waard is. Bepaalde woorden tot deze groep behorende hebben, naar het schijnt, een duidelijke voorliefde voor een bepaalde plaats in de zin: het begin en het eind: kĕlamarin aku bĕrtěmu děnan ...; kuda saya dilarikan orài sěmalam; vgl. ook tadi pagi saya pĕrgi kĕpasar. Ze duiden een min (kělak, dulu) of meer (kĕlamarin, sěkaraì) bepaalde tijd aan op of gedurende welke de beschreven gebeurtenissen (het proces) etc. plaats vinden. ${ }^{1}$ ) Het duidelijkste blijkt het verschil, wanneer we ze stellen tegenover lagi en těnah, die aspectuale wijzers bij het proces zijn (maka dilihatnya $S$. dan $D j$. itu lagi berrbantah „...(nog) aan het twisten waren”, ia těnah minum), waardoor te kennen gegeven wordt dat het proces aan de gang is, (nog) voortduurt. Geeft těnah het lineaire, duratieve, aspect aan, tĕlah het resultatieve etc. (vgl. ook sudah, maar ook

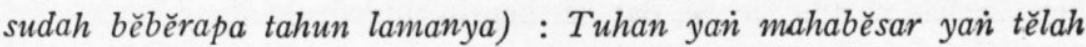
měnjadikan bumi yan luas; tuanhamba tĕlah lupalah akan ...; combinatie van tĕlah sudah is mogelijk: bukankah tělah sudah hamba katakan kěpada tuanhamba... (v. Oph., M.L., 45). In een zinnetje als ia tělah lama kĕnal kĕpada K. (P. Tj. 58) is tělah een quartaire ${ }^{2}$ ) term en subnex.

Op dezelfde plaats als de genoemde wijzers (dapat, hĕndak) staan de (modale) wijzers van negatie tiada, tidak (behalve wanneer het 'bij één woord behoort' in verbindingen als tiada siapa en sĕoran tiada „niemand”); masakan tiada dipěrcaya oleh baginda?; anak itu tidak berrtunañan; cf. rumah itu tidak běsar. Dit woord treedt eventueel voor dapat etc.: kilau ${ }^{2} a n$ tiada dapat ditěntan் nyata. Bijzonderheden betreffende de woordvolgorde zijn ook hier weer object van nader onderzoek. Evenzo bĕlum ,nog niet”. Zien we af van de corrigerende functie van bukan, dan is dit de negatie voor een substantief of zelfstandig pronomen dat als praedicaatswoord optreedt: paman saya bukan guru; bukan tuan yai saya paingil. Ook hanya "slechts” neemt deze positie, vóór het head-woord, in : ialah hanya sěorai் saja;

1) Woorden als sĕjurus die als bepaling van tijd optreden zijn in wezen van een telwoord voorafgegane 'maatwoorden'; zie boven, p. 295.

2) Zie boven, p. 307 . 
yà் mĕnĕtahui hanyalah Allah; ander gebruik van dit woord laten we rusten.

Een bepaalde lexikale kategorie van bepalingen van plaats kent het Maleis niet. Evenals een uitdrukking voor „elders” (pada tĕmpat lain) zijn de aequivalenten voor „hier”, „overal” enz. voorzetselgroepen: disini, dimana ${ }^{2}$. sini, sana etc. zijn substantieven (orai sini ,mensen van hier”; sini „deze plaats”). Bijzonderheden kunnen onbesproken blijven.

Welbekend zijn de woorden in Grieks, Latijn, Sanskrit e.a. talen, die een ander woord (resp. soms woordgroep) in de zin nader bepalen, maar tevens een subjectieve waardering uiten, welbekend ook om de moeilijkheid waarvoor ze de vertaler soms stellen, die de juiste nuance tracht te treffen. Men denke aan skt. eva, dat een woord releveert of souligneert met de betekenis van „precies, juist, niet anders dan" en dergelijke, aan kila, dat het voorafgaande woord naar voren haalt en er licht op laat vallen van een soms zelfs ironisch „natuurlijk, zoals je wel begrijpt”, aan $a p i$, aan het nadruksloze lat. quidem, dat achter het woord staat, welks begrip gereleveerd wordt, aan het Griekse partikeltje $\delta \eta^{\prime}$, dat het begrip uitgedrukt door het woord waarbij het zich voegt als niet te ontkennen, volkomen erkend of duidelijk voorstelt, aan het zo idiomatische Franse même, het Duitse wohl (,wohl steht ferner ähnlich wie zwar zunächst die Richtigkeit einer Aussage bekräftigend, aber mit dem Nebensinn, dasz Erwartungen, die man daran knüpfen könnte, nicht zutreffen" ${ }^{1}$ )); verder ook nog Nederlandse woorden als zelfs (zelfs Piet vindt het vandaag koud); tenminste (het is tenminste een fatsoenlijk man), juist. Meermalen vindt men cumulatie van dergelijke woordjes: gr. $\mu \dot{\varepsilon} v \pi o v$; du. doch wohl; ned. heus wel (hij is heus wel aardig in slang). Behalve door deze neiging tot cumulatie zijn deze woordjes vaak gekenmerkt door hun korte vorm (eensyllabigheid) en hun atoon of enclitisch karakter.

Tegenhangers van deze woorden in het Maleis zijn die welke sommigen ${ }^{2}$ ) modale partikels noemen. Ik zou van releverende subjectiverende partikels willen spreken ${ }^{3}$ ). Ertoe behoren o.a. juga: mĕlainkan ia juga měnunjukkan gagah-běraninya kěpada saya; baik juga

1) H. Paul, Deutsches Wörterbuch, s.v.

2) Vgl. Spat, o.c., § 211.

3) De Groot, o.c., p. 450 vat in het Latijn etiam, quoque, fortasse, certe, non etc., in het Nederlands zelfs, ook, wel, niet, misschien, juist etc. samen onder „determining particles, which may determine all sorts of words". Maar er zijn daaronder die meer dan één woord bepalen. 
aku masuk kĕdalam gua ini; mĕlainkan si $K$. jugalah yan் mĕlakukan děmikian itu (cumulatie; I.B. 32); jua, ook verbonden met pun: tiadalah sěhĕlai rumput jua pun; kěmbalilah jua ěnkau!; saja: mělainkan disĕrahkannya saja kĕpada ...; pula : siapa pula; ada pula dikasih běhagianmu. Voorts gěranian in vragen en bij onzekerheid: $a p a g$.; kĕmana g. pĕrginya; sěkalipun en kiranya (vgl.boven rupanya; agaknya) in zinnen die met jikalau aanvangen: $j$. patik mati s., sukalah patik ...; kiranya in wenszinnen: tuan bĕrhĕntilah $k$. sěběntar dirumah saya. Tot deze kategorie zijn ook te rekenen pun, lah, tah, kah, die door hun eensyllabige vorm en onzelfstandig karakter opvallen. Wat pun en lah in klassiek Maleis betreft, hiervan laat zich thans ${ }^{1}$ ) zeggen, dat zij - men denke aan het welbekende zinstype maka bagindapun bĕrankatlah dari sana (Sedj. Mel.) - dramatiseren, releveren en in (levendige) verhaaltrant - in directe rede ontbreekt dit zinstype geheel - de 'passé historique' uitdrukken; pun is daarbij steeds, lah lang niet altijd aanwezig. In het zinstype met inversie en lah - kĕmudian daripada itu maka bĕrhĕntilah raja $I$... (Sedj. Mel.), dat behalve in vragende zinnen en in bepaalde constructies eveneens optreedt waar gereleveerd en dramatisch verhaald wordt, is weliswaar de inversie het dragende element, doch lah eveneens idiomatisch ${ }^{2}$ ). Daarnaast treedt -lah bv. ook op in zinnen als: jainanlah adinda děnar pĕrkataan oran; lihatlah kita sěkaran்; apalah gunanya bĕrcakap tĕntan hal ini lagi?; cobalah lihatkan padaku gambarmu itu; sañatlah miskin nĕgěri itu; maka barulah pada hari ini aku kĕtahui enz. enz. De partikel tah verraadt, achter vragende voornaamwoorden, enig ongeduld : měnapatah tuanhamba bĕrkata dĕmikian ,waarom toch ...”; $k a h$ souligneert een vraag en staat achter het woord waarop de vraag speciaal betrekking heeft: tiadakah adindaku mĕlihat kakanda ... (P. Sem. 97); bunyi burun měrakkah itu?; met cumulatie: siapakah gĕraṅan yaì bĕrsama ${ }^{2}$ dĕnan ...? (P. Sem. 140). Al deze woorden staan achter het woord dat ze releveren of in de subjectieve sfeer trekken ${ }^{3}$ ). Ze komen achter woorden van verschillende woordsoort en sluiten zich daarbij, vaak nauw, aan.

In een zin als disuruh baginda hampir dari antara orà itu ěnam oraì kunnen we hampir een werkwoord noemen, in ia bĕrsěmbunyi

1) Zie Emeis, Vorm en Functie, vooral p. 86.

2) Over deze zinstypen in Modern Maleis Emeis, o.c., p. 147 vlgg.

3) Men kan verder bv. herinneren aan wat Adriani zegt over het enclitische $m o$ in Baré'e en andere talen van Celebes $(o$, mo etc.): Spraakkunst der Baré'e taal, § 300 . 
dibalik batu hampir tĕlaga ini een praepositie. Opmerkingen van gelijke strekking laten zich ten aanzien van meer Maleise woorden maken ${ }^{1}$ ). Men pleegt in de Maleise grammatika van voorzetsels te spreken en, als bij andere lexikale kategorieën, van een definitie af te zien. En inderdaad, er laten zich tal van gevallen citeren waarin het gebruik van een Maleis 'voorzetsel' dat van bv. een Nederlands volkomen dekt, ook als men afziet van leenvertalingen in het moderne Maleis (bv. Adi Negoro, Melawat ke Barat, p. 138 děmikianlah pula děnan rěncana saya těntan nĕgěri Bĕlanda ,zo is het ook met mijn verhaal over Nederland" ${ }^{2}$ ). Maar anderzijds loopt men ook hier vast, wanneer men consequent definities ontleend aan grammatika's van Indogermaanse talen voor een Indonesische taal zou willen overnemen, en dat niet alleen in zinnen waarin zowel oleh als agensen akan als patienswijzer voorkomen (type ditaikapnya akan tañanny S.D. oleh brahman itu). Hierop heeft Roolvink ${ }^{3}$ ) de nadruk gelegd. En inderdaad, definities als de door hem aangehaalde van Paul deugen niet voor het Maleis. Denkt men in de door Bally ${ }^{4}$ ) aangegeven richting, dan is het resultaat evenmin bevredigend: de praepositie is, zegt hij, een 'transpositeur' die van zijn 'transponend' „une détermination du verbe" maakt, en wel een transpositeur van „objets (autrement dit des substantifs)". Met zijn toelichting ben ik het niet eens: „C'est en apparence seulement qu'un groupe prépositionnel détermine un substantif ou un adjectif. D'une part, le 'complément du nom' implique toujours un ligament verbal, comme le prouvent les équivalences fonctionnelles: la maison de mon père est la maison qui appartient à mon père, qui est à mon père; quant à l'adjectif déterminé par un terme prépositionnel, tantôt il a une valeur verbale: une maison blanche de neige $=$ blanchie par la neige, tantôt il a la valeur d'un ligament lexicalisé : une bouteille pleine de vin $=$ qui a $d u$ vin". Men moet m.i. niet door substitutie van geheel of gedeeltelijk gelijkwaardige uitdrukkingen de typische eigenaardigheden van bestaande wendingen wegredeneren. La maison de mon père bestaat als nominale groep, de mon père is daarin een voorzetselgroep, maison en père zijn substantieven en de legt een verbinding tussen beide, treedt op als determinerend element etc. Zo zal men

1) Zie Roolvink, o.c., p. 70 vlg.; 72; 75; 76; 189 vlgg., e.a.

2) Zie Roolvink, o.c., hfdst. II, passim.

3) Roolvink, o.c., Inleiding, p. XI vlgg.

4) Ch. Bally, Linguistique générale et linguistique française, 2e ed. 1944, $\S 192$. 
ook in het Maleis de beantwoording van de vraag wat woorden als $d i, k \breve{e}$, dénan etc. in het systeem van de taal zijn, moeten funderen op de taal zoals ze is en niet op een bepaalde keuze uit de bestaande uitdrukkingsmogelijkheden. Hoezeer uiteraard zij toegegeven, dat vanuit een bepaald gezichtspunt reducties als de genoemde en andere (hij liegt $>$ hij is een leugenaar) hun bestaansrecht hebben.

Reeds Vendryes ${ }^{1}$ ) heeft gewezen op de punten van overeenkomst tussen bv. Franse praeposities die morfemen zijn (fr. le livre de Pierre: lat. liber Petri) met de 'mots vides' van de Chinese grammatika: 'volle woorden': semantemen, 'lege woorden': morfemen. Evenals chin. $t i$, dat een relatie van afhankelijkheid uitdrukt, als skt. $i t i$, dat een of meer woorden als geciteerd, als directe rede kenmerkt, als de optatief-partikel ă $v$ in het kl. Grieks zijn ǩe, dari, akan in het Maleis 'mots vides'; en wel woorden die relaties uitdrukken. $\mathrm{En}$, het is waar, veelal geven ze aan of verduidelijken ze de betrekkingen die bestaan tussen dat wat door het werkwoord wordt uitgedrukt en dat wat een daarmee syntaktisch verbonden substantief uitdrukt: kĕluar dari běnua Cina; měncěla akan binkisan raja ${ }^{2}$. Dat daarnaast in sommige gevallen wendingen zonder praepositie voorkomen (bv. masuk rumah, naast $m$. kĕdalam $r$.; měnajari si Anu) hebben we als begrijpelijk (vgl. bv. fr. prendre une ville en s'emparer d'une ville, ned. over de Ilias spreken en de Ilias behandelen of bespreken etc.) te constateren: men kan met Bally ${ }^{2}$ ) in die gevallen waarin een gewoonlijk of althans elders aanwezig ,ligament explicite” afwezig is van een ,ligament du type zéro”, een praepositie nul spreken. Voorts kunnen $d i, k \breve{e}$ en andere praeposities voor pronomina, pronominale suffixen en voor sini, mana en andere uitdrukkingen van plaats treden. Het gebruik van een praepositie voor een verbale vorm is niet onbekend: (surat) tĕrlalu sĕkali baik bunyinya děnan mĕrĕndahkan dirinya $(\text { H.T. })^{3}$ ), waar men van transpositie kan spreken: men kan $m . d$. vervangen door een substantief ${ }^{4}$ ). Wat niet wil zeggen, dat naast iedere constructie van deze aard een correcte aequivalente met substantief bestaat. Op het geval, dat een woord der hier besproken kategorie voor een verbale syntaktische groep treedt (těrlalu amat gěmpita bunyinya daripada kĕbanyakan ra $a^{\mathrm{c}}$ at ... měnirinkan

1) J. Vendryes, Le langage, Parijs 1921, p. 98 vlg.; 136 vlg.

2) Bally, o.c., \& 254 .

3) Vg1. Roolvink, o.c., p. 63 ; daarbij p. 174 en 179. Zie ook p. 114, onder IV.

4) Omgekeerd transponeert děnian in een adjectief in gevallen als sěoraì sattdagar... limpah harta děñan kĕmuliaan.

D1. 105. 
baginda itu), en waarbij men beter van conjunctionele functie kan spreken, komen we hieronder terug. Ook een 'niet-volledige' zin kan volgen: mĕmunut anak ... akan jadi biduanda (H.T.) ${ }^{1}$ ). Men kan akan hier als een clause-inleider (zie beneden) beschouwen.

Of een praepositie voor een woordgroep staat van de aard van t.a.b.b. in dipuñutkan inà் pĕnasuh akan tĕman anakanda baginda bĕrmain (H.T.) of voor een enkel substantief dipilih ěmpat anak pěrěmpuan akan daya $\dot{n}^{2}$ (H.T.), maakt geen wezenlijk verschil. Dat er - historisch gezien - in het Maleis 'secundaire praeposities' ontstaan zijn van het type diatas, dihadapan enz. verandert aan het principe niets, evenmin de mogelijke afwezigheid van het eerste deel van zo'n sec. praep.: antara i.p.v. diantara (mod. těrjĕpit antara kěkuatan yan் běsar ${ }^{2}$ ) e.a. Dat enige Maleise praeposities ook 'adverbiaal' kunnen fungeren, of, anders uitgedrukt, met complement nul kunnen voorkomen - Jespersen ${ }^{2}$ ) spreekt van ,complete in themselves” - is bekend: bawalah sahaya pěrgi sěrta (Sj. Bid.); vgl. ook dilihatnya suatu puan disisi naast bĕrdiri disisinya (Sj. Bid.). Zo ook kĕatas, kĕbawah etc.

Sommige verbindingen herinneren aan vaste verbindingen in Nederlands en elders ${ }^{3}$ ); zin hebben in, last hebben van, gebruik maken van, plezier beleven aan: běrbuat kĕbaktian kĕpada tuannya (H.T.); Abdoel Moeis, Salah Asoehan, p.9, mĕminta ma af atas kĕsalahannya; (moderne pers) měnambil bagian ... dalam ,aandeel nemen in”. In deze gevallen bepaalt het substantivisch deel van de aan de praepositie voorafgaande woordgroep welke praepositie wordt gebezigd. In een verbinding als (mod.) kasi tahu pada kan men tahu door allerlei andere woorden vervangen en toch pada op kasi( $h)$ laten volgen $\left.{ }^{4}\right)$. In verbindingen als měnjadi hamba kĕbawah is dit weer niet mogelijk, en bovendien laat mĕnjadi alleen zich niet als mĕnambil e.a. construeren. Naast deze uitdrukking vindt men echter ook apa dosa hamba kěbawah duli yan் dipěrtuan? (S.M.). En naast běrbuat kĕbaktian kĕpada: bĕsar kĕbaktiannya kĕpada (H.T.) ${ }^{5}$ ). M.a.w. Maleise praeposities treden ook op na substantiva, in de eerste plaats na die welke corresponderen met werkwoorden die met hetzelfde voorzetsel verbonden

1) Dergelijke gevallen zijn besproken door Roolvink, o.c., p. 40 .

2) O. Jespersen, The Philosophy of Grammar, p. 88.

3) Zie bv., met ten dele onjuiste terminologie, G. S. Overdiep, Stilistische grammatica van het moderne Nederlandsch, Zwolle 1937, § 233.

4) In hoeverre voorbeelden van deze verbindingen onder vreemde invloed ontstaan zijn, doet voor ons doel niet ter zake.

5) Zie Roolvink, o.c., p. 22; vgl. ook p. 131; 134. 
kunnen worden: (mod.) kĕinsafannya akan als insaflah akan ...! Zo pěnajaranku pada tuan naast bělajar pada ${ }^{1}$ ). Voorts treden voorzetsels op in gevallen als anak pada B.; tuan kĕpada hamba; A.D. děnan

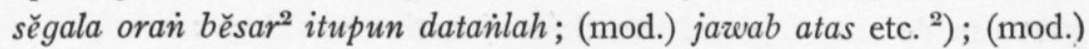
pěsuna kĕtakutan těrhadap těntěra Jěpan; kawan lama dari Hindia.

Wanneer we afzien van dari en daripada in de zin van ned. „dan” na een comparatief (lain dari itu etc.) komen praeposities achter adjectiva slechts op beperkte schaal voor. Bij adjectiva van bepaalde semantische kategorieën vindt men bepaalde praeposities: lěpas daripada; jauh dari; sama děnan; (mod.) kaya atas ,rijk van”; mulia kěpada „waardevol voor”; běnar kěpada; baik kĕpada; (mod.) lěbih mudah bagi saya. Een grondig syntaktisch, of, wil men, structureel onderzoek naar het Maleise adjectief zal interessante gegevens aan het licht kunnen brengen omtrent de labiele positie tussen adjectivum en verbum van woorden als paham, die soms met dalam (vgl. ned. knap in, doorkleed in), soms, als $t a h u^{3}$ ), met akan geconstrueerd worden. Bij ontwijfelbaar attributieve adjectieven schijnt geen praepositie voor te komen.

In sommige gevallen gaat aan een praepositie geen ander woord vooraf: men denke aan het releverende akan: akan A. tiada mĕmjěmbah raja ${ }^{2}$; akan sěkaran் ini.

Tot de voorzetsels valt ook te rekenen sĕpěrti (en synoniemen) „like, similar to, according to, as to"; het introduceert een substantief (event. woord van andere kategorie of woordgroep, uitdrukkende waarmee iets anders in gedrag, uiterlijk, rang, inhoud etc. overeenstemt, waarop iets anders gelijkt: s. sědiakala; s. gila lakunya; s. ombak mĕnalun rupanya; běnarlah s. bicara tuanhamba. Het kan substantivisch optreden: děnan sěperrtinya.

Het is meermalen opgemerkt, dat sommige Maleise woorden nu eens als voorzetsel, dan als 'conjunctie' fungeren, verschijnsel dat overigens niet tot IN. talen beperkt is : eng. come into the room after me: after he had arrived. "The only difference is”, zegt Jespersen naar aanleiding van dergelijke Engelse gevallen ${ }^{4}$ ), ,that the complement in one case is a substantive, and in the other a sentence (or a clause)". Zo moet men in de volgende Maleise zin karěna als een conjunctie beschouwen: Sj. Bid. 311, 19-20 tidaklah dapat ia bĕr-

1) Roolvink, o.c., p. 26.

2) Roolvink, o.c., p. 97.

3) Vgl. Roolvink, o.c., p. 168. tahu laat zich ook met pada verbinden.

4) Jespersen, o.c., p. 89. Vgl. ook Roolvink, o.c., p. 70. 
bainkit, karěna tubuhnya těrlalulah sakit. Behalve karěna zijn ook $s \breve{b} b a b$, hinga, oleh voor verbale syntaktische groep 'conjuncties'. Daarbij valt op te merken, dat hier de zinsconstructie geen invloed ondergaat van de aanwezigheid van de conjunctie: was deze afwezig dan zouden in het voorbeeld de woorden tubuhnya terrlalulah sakit in dezelfde volgorde optreden. Meermalen, evenwel, treedt de zgn. korte constructie $^{1}$ ) op: (mod.) (sěbuah auto) bĕrhěnti disana, karěna kěhabisan minyak. In het eerste voorbeeld volgde op karěna een complete Maleise zin, die als zelfstandig geheel dezelfde gedaante zou hebben, in het tweede geval wordt het onderwerp van kěhabisan, dat door een terugwijzend pronomen zou kunnen worden uitgedrukt, gesupprimeerd. Wat is het karakter van kĕhabisan minyak?

Onder bijzin (proposition subordonnée) pleegt men te verstaan een zin die in grammatikale ondergeschiktheid staat van een andere zin, en waarvan de betekenis op zichzelf onvolledig is, omdat deze om volledig te zijn afhangt van een andere zin, ondergeschikt is aan een geheel, deel uitmaakt van een periode. Een ondergeschikte zin kan zijn gekenmerkt door accent of afwezigheid van toon: in het Vedisch heeft het verbum in de ondergeschikte zin accent, in de hoofdzin niet. Of wel door de zinsmodulatie: ' $t$ is lichte kunst..., maar 't is aardig (d.w.z. hoewel het $l . k$. is, is het a.), door bepaalde voegwoorden, door een combinatie van een en ander: toen we pas in het bos waren, barstte een onweer los; bij waren hoort men, dat de zin nog niet af is. Evenzo door inversie in ondergeschikte zinnen zonder conjunctie: vgl. regent het? met regent het, dan blijven we thuis, d.w.z. in Nederlands, Duits etc. door een woordvolgorde, afwijkend van die van een hoofdzin: als ik naar $A$. ga: ik ga naar $A$. Er zijn talen die onderschikking op de wijze van Frans, Nederlands etc. niet kennen: de Dravidische bv., en het Australische Aranta. Voor de IN. talen, welker zinstypen een nog bijna onontgonnen terrein voor studie vormen, kan men overwegen o.a. van de term clause gebruik te maken, die in de Engelse grammatika wel gebezigd wordt om aan te duiden ,a short sentence, forming a grammatical unity in itself but not necessarily a complete, logical, or grammatical sentence". Zijn wij geneigd een Maleise zin (periode) als sětělah sampailah měntěri itu kĕpada nabi Chidir, maka iapun měmberri salam op te vatten als bij- en hoofdzin, in gevallen als sětělah sudah mandi maka istěri saudagar itupun měmangil hamba sahayanya zou men mutatis mutandis de drie

1) Emeis, Inleiding 2 , p. 169 vlgg. 
eerste woorden te samen een clause kunnen noemen. Na sĕtĕlah zijn, in zo'n korte constructie, verschillende werkwoordsvormen mogelijk. $\mathrm{Na}$ sambil, sěraya en sĕrta echter, die thans als regel door een korte constructie gevolgd worden, wordt tegenwoordig bijna uitsluitend de mĕ-vorm gebezigd: ... ada duduk nyonyanya sambil měmĕluk sěbuah tas; maka diambillah oleh si $M$. itu sĕraya mĕnyĕmbah. Wij kunnen in de Nederlandse vertaling een conjunctie gebruiken. Het is welbekend, dat het Frans, speciaal het geschreven Frans, vele wendingen kent, die bv. het Duits met bijzinnen weergeeft: après avoir pris congé, il sortit; ils courent à leur père ... en secouant leur becs; à la voir, on ne la dirait pas malade. De Maleise korte constructies met sambil etc. herinneren, mutatis mutandis, hieraan. Men denke, behalve aan voorbeelden als de genoemde, aan: sěbělum turun ayah $R$. bĕrkata ...; maka I.B. pun heranlah sĕraya mĕn்cap syukur kĕpada A.; jikalau běrjalan tĕrus saja tuan tiba dipasar. Wil men dergelijke gevallen waarin clauses van de onvolledige soort (verbum; verbale syntaktische groep enz.) optreden als zinnen met een onzelfstandig, onvolledig, ondergeschikt deel onderscheiden van 'perioden', welke een volledige, maar afhankelijke zin bevatten (bv. boleh jadi san்ka měreka bahwa mĕrekalah yan் mula sĕkali měndiami daerah $i t u$, dan kan men onder de dusgenaamde conjuncties twee groepen onderscheiden - met dien verstande, dat sommige zich in beide laten classificeren: (auto) běrhěnti..., karěna kĕhabisan minyak, naast tidak ubahnya sěbagai tikus yan் lari karěna kapal hampir těngělam. Karěna in dit eerste voorbeeld, sambil, sĕraya etc. leiden een clause in, die geen uitgedrukt subject bevat of kunnen, afgezien van dit laatste, 'invloed op de constructie' hebben (sětělah sampai mĕntěri itu kĕpada nabi Ch., maka iapun měmběri salam. In ieder geval is echter de syntaktische groep die zij inleiden onvolledig, niet af of als zin op zich zelf ongewoon van woordvolgorde. Met de 'conjuncties' waarachter een volledige zin optreedt hebben deze gemeen, dat ze een proces in een bepaling van een proces transponeren; ze drukken een betrekking uit en wel een van toevoeging aan een proces. De benaming 'conjunctie' zou hier misverstand kunnen wekken; men zou van onderschikkende zinswoorden kunnen spreken of van clausewoorden, clause-inleiders. De term onderschikkend voegwoord of -e conjunctie kan men dan bezigen in gevallen als dalam bond itu $P$. dan O. bĕradu kěkuatan, hinga achirnya kĕdua sahabat itu běrpisah (hinga).

Bezien we deze woorden even van diachronisch-vergelijkend ge- 
zichtspunt. De talen, die aan het Maleis na-verwant zijn hebben over het algemeen relatief weinig voegwoorden en verschillen in wat ze hebben onderling aanmerkelijk. Ook in de IdG. talen lopen de gebezigde voegwoorden sterk uiteen. Er zijn stadia en fasen van beide taalfamilies, waarin het vaak onjuist is van bijzin te spreken in de zin van de traditionele schoolgrammatika. Ook is vaak criterium voor een bijzin niet het optreden van een - soms facultatief - voegwoord, maar zinsmodulatie etc. Leerzaam is bv. de ontwikkelingsgang van de Romaanse talen. Het populaire taalgebruik ten tijde van het Romeinse rijk kende op grote schaal de constructie met quod, ook waar het klassieke Latijn andere constructies had (bv. credo quod terra est rotunda). Vele Latijnse conjuncties vielen samen in dit quod $(>$ fr. que), dat bovendien vaak kon wegblijven. „L'ancien français se contente volontiers d'un à-peu-près. Il lui suffit de se faire comprendre; il ne sent pas le besoin d'exprimer tout selon les règles d'une logique impeccable" ${ }^{1}$ ). Juxtapositie overheerst sterk in de zinsbouw, lange perioden met hoofd- en bijzinnen zijn hoogst zeldzaam, de ondergeschikte zin op zichzelf al wordt aanmerkelijk minder gevonden dan in de tegenwoordige taal; een uitzondering vormen de hypothetische en de relatieve zinnen. Deze neiging tot juxtapositie - vaak beter : oppositie - is een kenmerk van zgn. populaire taal. De hogere intellectuele eisen van latere eeuwen, toen de taal des volks meer en meer in gebruik kwam voor hogere geestesuitingen, drongen tot meer nauwkeurige uitdrukking der betrekkingen: de vage 'juxtapositie' voldeed niet langer, de onderdelen van een-mededeling werden in nader verband tot elkaar gebracht en er ontwikkelden zich termen tot het uitdrukken van dat verband: voegwoorden. Het Frans ging de passe-partout conjunctie que verduidelijken met toevoeging van adverbia of adverbiale uitdrukkingen, vandaar par ce que > parce que, quoique, bien que etc. Niet alle verbindingen die zo ontstonden zijn bewaard gebleven, doch de volkstaal voegt er, aan de andere kant, nieuwe aan toe: à seule fin que etc. De behoefte tot verduidelijking, verlevendiging drijft de sprekers tot meer expressieve verbindingen (lat. usquedum i.p.v. dum; populair fr. jusqu' à tant que: tant que, jusqu' à que; vgl. mal. agar supaya en derg.). Ook in IdG. talen gaat een deel der conjuncties op praeposities terug ${ }^{2}$ ). Sommige voegwoorden drukken oorspronkelijk een vergelijking uit: du. übrigens, gleich-

1) W. von Wartburg, Évolution et structure de la langue française ${ }^{3}$, Bern 1946, p. 97.

2) Zie bv. H. Paul, Prinzipien der Sprachgeschichte ${ }^{5}$, § 119; 259-261. 
falls, fr. mais < lat. magis etc. Termen uit een volgende zin kunnen nevenschikkend voegwoord worden, wanneer ze terugslaan op de voorafgaande zin: vgl. fr. il pleut, pourtant (= pour cela) je sors, naast $i l$ pleut, je sors malgré cela, en naast il pleut, à cause de cela je ne sors pas ${ }^{\mathbf{1}}$ ).

Een naar volledigheid strevende syntaxis van het Maleis, die ook het diachronisch gezichtspunt niet mag verwaarlozen, zal op interessante ontwikkelingen kunnen wijzen: kĕtika, bv. dat eens substantief was (,ogenblik”): pada kětika itu, kan thans in de kategorie der conjuncties compareren:pěrdana měntěri, kĕtika hĕndak bĕrainkat,bĕrjabatan tanan dĕnan pĕmimpin. Hoe uit skt. kārana- ,redenen, motief, oorzaak" de Maleise conjunctie karěna zich heeft ontwikkeld, is nog na te gaan ${ }^{2}$ ) en grotendeels parallel lijkt de geschiedenis van het synonieme, van oorsprong Arabische sěbab ${ }^{3}$ ). De oorspronkelijke andere functie van deze woorden, de losse samenhang der zinnen, ook al maken karĕna etc. de indruk van conjuncties, is nog vaak duidelijk. Merkwaardig ingeburgerd is - dit par parenthèse - ook het skt. niçcaya- ,overtuiging etc.” aan het hoofd van een nazin na voorzin met jika(lau): jika kakanda tahu akan adinda mĕmbunuh diri, niscaya tiadalah kakanda tingalkan adinda ini (S.B. 97). Een interessante ontwikkeling heeft ook bahwa (van oorsprong skt. bhāva„waarheid, wezenlijke aard etc.”, vgl. mal. děnan sěbahwwa „wezenlijk, inderdaad"), als interjectioneel woord of aanhef-term (sjahdan bahwa adalah saudagar itu těrlalu kaya...), aan het begin van geciteerde woorden en dan inleider van een bijzin : tiada sayogianya bahwa sahabat itu diperrdayakan. Het is verder welbekend, dat ook inheemse woorden heel duidelijk een functie er bij hebben gekregen. Een belangwekkend geval van transpositie vertegenwoordigt bv. het moderne gebruik van biar: als modaliteitswijzer drukt het woord uit:,,laat... (maar)": biarlah aku kĕmbali dahulu, thans kan het een woordgroep, een clause of een bijzin inleiden en vertaalbaar zijn hetzij met ,ofschoon, ook al": saya mau běli baran் biar mahal sĕdikit, hetzij met „opdat”: nanti aku ichtiarkan biar kita bĕroleh kĕsěnañan ${ }^{4}$ ). Een aanmerkelijke verschuiving in gebruik vertoont ook hĕndaknya, dat, eerst modaliteitswijzer, thans als onderschikkend zinswoord kan fun-

1) Uitvoeriger behandeld door Ch. Bally, Linguistique générale et linguistique française ${ }^{2}$, Bern 1944, § 94 .

2) Roolvink, o.c., p. 70 vlg.

3) Roolvink, o.c., p. 72 vlg.

4) A. A. Fokker, Beknopte Maleise grammatica2, 1946, p. 111. 
geren: ia měnhadap hĕndaknya tĕrdapat pěrtalian pĕrsahabatan ,hij hoopte dat er een bestendige vriendschapsband zou bestaan". En dan - wat ook de herkomst van het woord moge zijn - kalau ${ }^{2}:$ kala $^{2}$ luputlah ia daripada bahaya itu (,misschien”) en saya takut, kalau ${ }^{2}$ ia tiada datain.

Er zijn ook in het Maleis conjuncties wier optreden niet verplicht behoeft te zijn: kita běrmohon (supaya) mudahªn akan dipěliharakan kita ${ }^{\mathbf{1}}$.

Dit supaya is tevens weer een geval van een 'conjunctie' met 'invloed op de constructie' : suruhlah anakku raja M. měnadap aku kĕmari supaya aku dudukkan děnan anakku tuan putěri. Vgl. ook Indera B. 8 sětělah běbĕrapa lamanya ia bĕrjalan itu maka ... met 6 běbĕrapa lamanya ia běrjalan mělalui hutan etc. (zie ook boven).

Er zijn echter ook gevallen, waarin een 'conjunctie' weliswaar aan een syntaktische groep voorafgaat die op zichzelf volledig is en op zich in normale taal de woordvolgorde heeft of kan hebben die hij heeft, maar ze toch staat aan het hoofd van een geheel dat een complement behoeft, dat, behalve in aposiopese etc., zonder complement niet voorkomt. Bv. jikalau tuanhamba lěpas in j.t.l. yan் dipěrtuan murka akan hamba, de groepen kalau ia dataì en sěbělum aku pulan in k.i.d.s.a.p. suruh ia duduk dahulu. Men zou ook denken aan maka, wanneer het staat in zinnen als (mod.) kalau ada těrdapat kĕjahatan, maka pěnhulu itu mĕsti sĕgĕra měmběri tahukan hal itu kĕpada raja; siapa yan் lěbih lanjut hĕndak mĕnĕtahui tĕntan் soal ini, maka baiklah ia měmbaca buku itu ${ }^{2}$ ).

Er zijn ook formeel gekenmerkte conjuncties in het Maleis. Al kan men naast sĕbĕlum ook bĕlum vinden aan het hoofd van een clause (bělum dipandan, kasih dahulu), toch is sěbělum de typische vorm van de conjunctie: sěbělum kita mĕrĕncanakan pěrlawatannya itu, baiklah... Zo sĕlama ,zolang”, supaya ,opdat” (sĕ + upaya ,(hulp)middel"). Concessieve conjuncties hebben graag pun achter zich: měski(pun), suñguhpun etc. Maar het enige gebruik van š̌- en pun is dit niet.

Conjuncties van deze aard (die aan het begin van een zin staan die in een relatie van subordinatie een complement veronderstelt) en die de aard van het verband tussen deze zin en een andere (nader)

1) Fokker, o.c., p. 115; voorts Fokker, p. 110. Men kan voorts naslaan: Gerth van Wijk, o.c., p. 292 vlg.

$\left.{ }^{2}\right) \mathrm{Zie}$ ook Emeis, Inleiding ${ }^{2}$, p. 182 . Men vindt maka ook voor de korte constructie: apa dosanya oran muda ini maka disula oran்? 
aanduiden, die alleen als zodanig optreden zijn, al met al, schaars: jikalau, het ontleende en weinig frequente agar e.a.

Coördinerende voegwoorden zijn o.a. tětapi en itupun, die een tegenstelling uitdrukken. Een woord als tĕtapi verbindt weliswaar twee zinnen die met elkaar in een relatief nauw verband staan, maar niet onmogelijk zijn zonder elkaar: iapun bĕrjalanlah mĕncahari anaknya, tiada bĕrtěmu juga naast maka ditěrkamnyalah oleh harimau tĕtapi tiada dapat olehnya. Men denke voorts aan lagipun ,en bovendien”: bukankah musim ini musim pĕrompak Lanun, lagipun musim ribut. De woorden lalu en sĕrta vertegenwoordigen een bijzonder geval. $\mathrm{Na}$ lalu ,vervolgens” vindt men meestal de korte constructie, al is volledige uitdrukking van subject en praedicaat, al of niet met inversie, mogelijk: maka iapun mĕmasukkan sarun kĕsaktiannya lalu bĕrjalan; maka iapun marahlah lalu měnyĕrbukan dirinya kĕdalam tĕntĕra itu...; patik takut lalu patik naik kĕatas pohon kayu; bij wisseling van subject treedt ia op: maka dilihatnya tuan putĕri ... bĕradu, lalu ia kĕluar (I. Bangs.). Vgl. ook sĕrta: sětělah sudah mandi lalu bĕrsalin kain sěrta duduk (I. Bangs.). Het woord lalu coördineert, het voegt, met of zonder 'invloed' op de constructie, een proces aan een proces toe. Het veronderstelt steeds een voorafgaand proces, althans praedicaat. Daarin verschilt het van het klassieke coördinerende maka, dat (evenals andere min of meer synonieme termen) ook kan optreden als er geen proces voorafgaat: maka bagindapun tĕrkějutlah mělihat ...; maka tĕrsĕbutlah pĕrkataan ... etc. Evenals maka kan lalu na een sĕtělah-clause optreden: sĕtělah sampai lalu měnyěmbah; sětělah sudah maka I.B. mĕmasukkan sarun kĕsaktian. Zijn coördinerende karakter heeft lalu gemeen met dan, dat (hoewel zelden) zinnen (I.B. 32 dari manakah datannya itu dan kĕmana pula pěrginya?), maar ook woorden verbindt: matahari dan bulan; mĕmbĕli dan mĕnjual. Het kan echter wegblijven evenals het disjunctieve atau: gajah atau kuda; adakah ia atau tiadakah. Vgl. daarbij bv. ook mĕlainkan.

Een groepje van verklarende 'tussenzetsels' heeft het Maleis in $y a^{\mathrm{e}} n i$; yaitu enz. „that is to say; nl.”: jikalau kita alah olehnya, ya'ni tiada tĕrtahan lagi (I.B. 33); disitu adalah sěoran் sahabatku yaitu sěoràn saudagar. Evenals interjecties, waarvan ze zich door hun begripsinhoud onderscheiden, staan ze buiten (resp. onderbreken ze) het syntaktisch verband.

Komen we tenslotte tot de interjectie. Evenals in andere talen valt de Maleise interjectie vaak op door zijn afwijkende vorm: er zijn 
verscheiden monosyllaba bij : ya, cus, hai, ook trisyllaba als aduhai (=aduh hai); er zijn fonologische bijzonderheden als de $o i$ in amboi. Vgl. ook bim. ai; hai e.a.; jav. hus; his; hèh; hĕm; hara (initiale h), etc. Voorts kunnen ze verschillende primitieve kenmerken vertonen (affectieve verdubbeling zoals in k. bat. iah iah!; klanksuggestie etc.), waarover ik elders uitvoeriger gehandeld heb ${ }^{1}$ ). Esser ${ }^{2}$ ) mag in een enge definitie van het begrip 'grammatika' - en omdat ,ze zich in geen enkel opzicht onderscheiden van interjecties van andere talen" - een motief vinden ze onbesproken te laten, in een taalbeschrijving die zich geen nauwere grenzen oplegt dienen ze behandeld te worden, in de taalstructuur nemen ze hun plaats in. Weliswaar staan ze als afzonderlijke kategorie tegenover de overige ${ }^{3}$ ). Zijn de andere lexikale kategorieën 'darstellend', de interjecties zijn dit niet. Ze laten zich niet substantiveren. Ze zijn, zoals áy in het Chamoro, dat lichamelijke of geestelijke pijn vertolkt of zoals $e h \bar{e}$ in diezelfde taal, dat spot en geringschatting bij de spreker verraadt, ,,reine Empfindungswörter”4), op conventionele wijze overigens ${ }^{5}$ ); ze drukken, zoals men het soms formuleert ${ }^{6}$ ), veel met weinig woorden of alleen een gehele gedachte uit. „They are position words”, zegt De Groot ${ }^{7}$ ), ,namely words with which the speaker takes position toward something that is not 'dargestellt' in the sentence, but is present in the speech-situation". Zoals we boven al gezegd hebben ${ }^{8}$ ), laten echter interjecties of als zodanig fungerende woorden zich, als regel, niet in syntaktisch ondergeschikte positie gebruiken, men kan ze wel in de zin, 'buiten syntaktisch verband' invoegen of onderling aaneenrijgen. Vgl. jav. duh, mahăçakti dahat sañ pandita (T. Pangg.); mal. ah, masakan saya dapat jamu $l a k i^{2}$. Uiteraard zijn er grens- en twijfelgevallen: ned. gò, jé; bare'e waja (ook tot wuanto vervormd), dat, uitroep van verwondering of verstoordheid, op zenaja ,krokodil” teruggaat. Men zal, wanneer voor de spreker geen enkele band met ,krokodil” bestaat, van een interjectie mogen spreken. Daarentegen zal men een woord als mal. mari

1) Some remarks on onomatopoeia etc., T.B.G., 80 (1940), p. 133 vlgg., en speciaal p. 158 vlgg.

2) S. J. Esser, Klank- en vormleer van het Morisch, 1933, p. 242.

3) Zie thans uitvoeriger: De Groot, o.c., p. 473 en 481.

4) H. Costenoble, Die Chamoro Sprache, 1940, p. 271 vlg.

๘) Nader bij E. Sapir, Language, p. 4 vlg.

6) Zie bv. Costenoble, o.c., p. 272 en J. H. Neumann, Schets der KaroBataksche Spraakkunst, 1922, p. 135.

ๆ) De Groot, o.c., p. 474.

8) Zie p. 276 vlg., waarnaar ik verder verwijs. 
(mari kita pulan; marilah saya jinjinkan tas itu) niet als interjectie maar als specimina van bijzonder gebruik van werkwoordsvormen (vgl. coba, toloxi) moeten beschouwen. Tot de hier besproken interjecties moet men, strikt genomen, evenmin rekenen de zgn. werkwoordelijke tussenwerpsels die in het Soendaas bv. zo veel gebruikt worden, om het even of ze 'klanknabootsend' (bruk „ploef”; gurudug van het rollen van een wagen) zijn of niet. Ze staan weliswaar buiten het syntaktisch verband, maar de spreker neemt er wel positie mee tegenover iets dat in de zin, nl. door het werkwoord wordt uitgedrukt: bruk... nambru batur kolot teh ,ploef!, daar stortte de oude dienaar neer". Over hypostase of transpositie van deze 'wwd. tussenwerpsels' of 'redewoorden' was boven al sprake (soend. $p o k)^{1}$ ): in soend. sawarah mah cul pakaran ,sommigen wierpen hun wapens weg” fungeert $c u l$ als werkwoord.

Kan men met schrijver dezes in hoofdzaak in beschouwingen als de bovenstaande treden, dan zal men moeten toegeven, dat men ook voor een Indonesische taal een indeling van het woord-materiaal kan geven. Al wijkt deze indeling - maar dit is a priori te verwachten af van de traditionele der Latijnse schoolgrammatika. Al stuit men op zeer vele grensgevallen, op tal van woorden, die ambi- of plurivalent zijn, op zeer ruime mogelijkheid tot transpositie en hypostase. En al zijn bij de leden van een zelfde groep lang niet altijd alle kenmerken die men aan die groep in het algemeen kan waarnemen aanwezig.

Voor hen die een kort overzicht op prijs stellen zou men wellicht het besprokene als volgt kunnen samenvatten, - met het voorbehoud evenwel dat bij een nader onderzoek van bepaalde woordkategorieën nog een en ander kan verschuiven: we hebben hier slechts een eerste verkenning en globale behandeling geboden.

1 Buiten syntaktisch verband, uitdrukkend zonder 'Darstellung': interjectie (hai);

2 -, explicerend: explicatief 'tussenzetsel' $\left(i a^{\mathrm{e}} n i\right)$;

3 , evenals alle volgende, in syntaktisch verband en 'darstellend', evenals 4 tot en met 16 'benoemende' woorden, evenals 4 tot en met 12 geen betrekking hebbende op relatie, evenals 4 tot en met 10 niet als proces gedacht en evenals 4 betrekking hebbend op

1) Zie ook Adriani, o c., p. 409. 
substantie, en wel klasse-'aanduidende woorden': appellativa, in twee ondergroepen: niet 'maatwoorden' en abstracta (rumah, saudagar) en 'maatwoorden' (hasta, jurus); abstracta (kěsopanan);

4 individu-'aanduidende woorden': eigennamen, in twee ondergroepen: persoonsnamen ( $s i A l i)$ en wat zich daarbij aansluit en geografische namen (sunai Jambi) etc.;

5 , evenals 6 tot en met 10 betrekking hebbend op accidens ${ }^{1}$ ), en wel, subjectief, bij woorden van verschillende kategorie: bepalingspartikels (juga, pun);

6 , evenals 7 tot en met 10 , 'objectief' - inzoverre men ook modaliteit 'objectief' kan noemen -, bij woorden van bepaalde kategorie(ën), evenals 7 bij het substantief, en wel niet tellend: adjectiva (muda, běsar);

7 tellend, in twee groepen: bepaalde (hoofd)telwoorden (lima) en onbepaalde telwoorden $\left(\right.$ tiap ${ }^{2}$; sěgala);

8 accidens bij accidens: adverbia (amat);

9 accidens bij proces, en wel modale, temporale en aspectuale wijzers (dapat; hĕndak) etc.;

$10-$, en wel bepalingen van tijd (sěkaraì; kĕlak); -9 en 10 , hoewel niet als proces gedacht staan wel in relatie tot tijd - ;

11 tot en met 13 verbale klassen (gedacht als proces), waarvan 11 transitiva (buka, dibuka(nya), měmbuka);

12 intransitiva (tidur; mĕnyěbĕrài) (waaronder enkele ook in bijzonder gebruik als 'koppelwerkwoord' (jadi));

13, evenals 14 tot en met 16, betrekking hebbend op relatie, en wel evenals 14, coördinerend: in het algemeen (dan, atau), en :

14 zinnen of clauses verbindend (tětapi; lalu);

15 , evenals 16 subordinerend, en wel substantiva etc. verbindend;

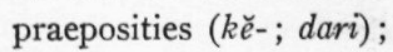

16 zinnen of clauses verbindend (sambil; jikalau);

17, evenals 18 tot en met 21 'aanduidende' woorden (voornaamwoorden), en wel van substantie: zelfstandige voornaamwoorden (saya, ia);

18 bepalende, 'aanwijzende': zgn. pronomina demonstrativa (ini; itu);

19 vragende, en wel zelfstandige (siapa);

20 -, en wel bijvoeglijke (mana);

1) Zie De Groot, o.c., p. 476 . 
PROLEGOMENA DER WOORDSOORTEN IN INDONESISCHE TALEN. 331

21 in het 'Denkfeld' liggende releverende persoonswijzers, die wel $(y a \dot{n})$ of niet $(s i)$ aan een voorafgaand zinsdeel kunnen aanknopen.

Men kan ook trachten deze woordklassen anders te benoemen en anders te groeperen, bv. $13 \mathrm{t} / \mathrm{m} 16$ en 21 grammatikale woorden te noemen, 6,7 en 18 samen te vatten onder 'accidens van substantie' etc. 